\title{
Role of the Southern Annular Mode (SAM) in Southern Ocean $\mathrm{CO}_{2}$ uptake
}

\author{
Andrew Lenton ${ }^{1}$ and Richard J. Matear ${ }^{2,3}$ \\ Received 6 March 2006; revised 8 March 2007; accepted 20 March 2007; published 30 May 2007.
}

[1] A biogeochemical ocean general circulation model, driven with NCEP-R1 and observed atmospheric $\mathrm{CO}_{2}$ history, is used to investigate and quantify the role that the Southern Annular Mode (SAM), identified as the leading mode of climate variability, has in driving interannual variability in Southern Ocean air-sea $\mathrm{CO}_{2}$ fluxes between 1980 and 2000. Our simulations show the Southern Ocean to be a region of decreased $\mathrm{CO}_{2}$ uptake during the positive SAM phase. The SAM induces changes in Southern Ocean $\mathrm{CO}_{2}$ uptake with a 2-month time lag explaining $42 \%$ of the variance in the total interannual variability in air-sea $\mathrm{CO}_{2}$ fluxes. Our analysis shows that the response of the Southern Ocean to the SAM is primarily governed by changes in $\triangle \mathrm{pCO}_{2}(67 \%)$, and that this response is driven by changes in ocean physics that control the supply of nutrients to the upper ocean, primarily Dissolved Inorganic Carbon (DIC). The SAM is predicted to become stronger and more positive in response to climate change and our results suggest this will decrease the Southern Ocean $\mathrm{CO}_{2}$ uptake by $0.1 \mathrm{PgC} / \mathrm{yr}$ per unit change in the SAM.

Citation: Lenton, A., and R. J. Matear (2007), Role of the Southern Annular Mode (SAM) in Southern Ocean $\mathrm{CO}_{2}$ uptake, Global Biogeochem. Cycles, 21, GB2016, doi:10.1029/2006GB002714.

\section{Introduction}

[2] The Southern Ocean, with its energetic interactions between the atmosphere, ocean and sea ice, plays a critical role in ventilating the global oceans and regulating the climate system though the uptake and storage of heat, freshwater and atmospheric $\mathrm{CO}_{2}$ [Rintoul et al., 2001; Sarmiento et al., 2004a]. Recent studies suggest that the formation of Sub-Antarctic Mode Water (SAMW) alone may be responsible for as much as $40 \%$ of the uptake of anthropogenic $\mathrm{CO}_{2}$ by the oceans [Sabine et al., 2004]. The uptake of $\mathrm{CO}_{2}$ in the Southern Ocean is primarily through air-sea fluxes which are both poorly sampled and highly variable [Louanchi et al., 1999; McKinley et al., 2004; Sabine and Key, 1998]. Consequently, the carbon budget remains poorly constrained with large uncertainties in the global carbon budget and hence in the predicted response to climate change.

[3] Air-sea $\mathrm{CO}_{2}$ fluxes can be described as a combination of seasonal and nonseasonal variability. In the Southern Ocean seasonal cycle, a complex interplay between biological production and deep winter mixing, is the dominant

\footnotetext{
${ }^{1}$ Laboratoire d'Océanographie et du Climat: Expérimentations et Approches Numériques (LOCEAN/IPSL), Université Pierre et Marie Curie, Paris, France.

${ }^{2}$ CSIRO Marine and Atmospheric Research (CMAR), Hobart, Tasmania, Australia.

${ }^{3}$ Antarctic Climate and Ecosystem Cooperative Research Centre (ACE CRC), University of Tasmania, Hobart, Tasmania, Australia.

Copyright 2007 by the American Geophysical Union. 0886-6236/07/2006GB002714
}

mode of variability. The mechanisms that drive seasonality are well known but the magnitude remains poorly constrained [Louanchi and Hoppema, 2000; Louanchi et al., 1999; Metzl et al., 2006, 1999, 1995; Roy et al., 2003]. In the Southern Ocean the nonseasonal variability, particularly interannual variability, can also be large [Jabaud-Jan et al., 2004; Metzl et al., 2006]; but the interannual changes in biological production, ocean dynamics and thermodynamics that drive these changes are poorly understood and therefore poorly quantified at the interannual timescales. The sampling study by Lenton et al. [2006] showed that the nonseasonal variability, dominated by interannual variability, was responsible for the largest component of the uncertainty in the annual mean uptake of $\mathrm{CO}_{2}$ by the Southern Ocean.

[4] Studies have identified the Southern Annular Mode (SAM), which is characterized by changes in atmospheric mass between $20^{\circ} \mathrm{S}$ and $90^{\circ} \mathrm{S}$, as the dominant mode of climate variability in the Southern Hemisphere [e.g., Thompson and Solomon, 2002; Visbeck and Hall, 2004]. The SAM induces changes in the strength of westerly winds which have been shown to induce significant changes in ocean circulation [Hall and Visbeck, 2002; Oke and England, 2004]. These include: (1) changes in the strength of northward Ekman Flow and increased upwelling along the Antarctic Continent; (2) changes in the vertical tilt of the isopycnals; (3) downwelling around $45^{\circ} \mathrm{S}$ and (4) changes in the strength of the Antarctic Circumpolar Current (ACC) resulting in changes in mixed layer depth and oceanic heat transport. The SAM is also known as the Antarctic Oscillation (AAO) [Gong and Wang, 1999] and the High Latitude Mode (HLM) [Rogers and van Loon, 1982]. 
[5] The Northern Annular Mode (NAM), also known as the North Atlantic Oscillation (NAO) or Arctic Oscillation (AO) has been shown to play an important role in driving interannual variability in air-sea $\mathrm{CO}_{2}$ fluxes in the Northern Hemisphere [Gruber et al., 2002; Russell and Wallace, 2004]. It is logical then to explore and quantify whether the SAM plays a similarly important role in driving interannual variability in Southern Ocean $\mathrm{CO}_{2}$ fluxes. This study is unique; no previous studies exist that quantify the air-sea $\mathrm{CO}_{2}$ flux in the Southern Ocean and the relative importance of its drivers in response to the SAM.

[6] Hall and Visbeck [2002], using a physical only ocean model, hypothesized that in its positive phase the SAM would drive a strong decrease in the $\mathrm{CO}_{2}$ uptake, due to the increased upwelling of Dissolved Inorganic Carbon (DIC). This predicted response appears to contradict a recent study based on remotely sensed observations [Lovenduski and Gruber, 2005] that looked at the effect of the SAM on the entire carbon cycle over nonseasonal timescales. Lovenduski and Gruber [2005] suggested that when integrated over the entire Southern Ocean between the Subtropical Front (STF) and the Antarctic Continent, the SAM would elicit only a moderate net $\mathrm{CO}_{2}$ flux response. They suggested that while upwelling of nutrient rich waters did occur in response to the SAM, this effect was offset by changes in export production and solubility.

[7] Present climate change projections suggest that the amplitude of the SAM will increase and become more positive in future decades (i.e., stronger and more sustained increases in zonal wind stress) [Cai et al., 2003; Kushner et $a l ., 2001]$. If we can understand and quantify the interannual variability in $\mathrm{CO}_{2}$ air-sea fluxes explained by the SAM from 1980-2000, this relationship may be able to be used to predict the response of the Southern Ocean carbon cycle to climate change.

[8] As the Southern Ocean remains one of the most poorly carbon sampled regions globally, we used a prognostic Biogeochemical Ocean Global General Circulation Model (BOGCM). In this study we used the Commonwealth Scientific Industrial Research Organisation (CSIRO) Mark 3 model, driven with NCEP-R1 atmospheric forcing and observed $\mathrm{CO}_{2}$ history, to simulate the interannual variability of the Southern Ocean carbon cycle, for the period 1980-2000. We defined the Southern Ocean to be the region of ocean bounded by $40^{\circ} \mathrm{S}$ and the Antarctic Continent.

[9] This paper examines and quantifies the response to the SAM of $\mathrm{CO}_{2}$ fluxes in the Southern Ocean and in each of its ocean sectors. This paper is structured as follows: in section 2 we describe our methodology; section 3 presents our results; and section 4 gives our conclusion and discussion. In this final section we compare our results to other studies and suggest what impact the predicted role of the SAM under climate change may have on Southern Ocean $\mathrm{CO}_{2}$ uptake.

\section{Simulation and Approach}

\subsection{Modeling the Southern Ocean}

[10] To compensate for the lack of observed air-sea $\mathrm{CO}_{2}$ fluxes, a prognostic 3D Biogeochemical Ocean General Circulation Model (BOGCM) was used. A global domain model was used thereby avoiding any problems related to open boundary conditions. The ocean general circulation module (OGCM) of the BOGCM was based on the $\mathrm{Z}$ coordinate Modular Ocean Model (MOM)-Version 3 [Pacanowski and Griffies, 1999]. The model grid has a horizontal resolution of $0.94^{\circ} \mathrm{N}-\mathrm{S}$ and $1.9^{\circ} \mathrm{E}-\mathrm{W}$ at the equator with a tapering of longitude as a function of the cosine of latitude (T63-2) and 31 nonregular vertical levels, 15 levels in the upper $500 \mathrm{~m}$. To represent the effects of eddies not simulated in the model, the eddy parameterization of Gent and McWilliams [1990] was implemented, as was the Chen mixed layer scheme [Chen et al., 1994] to parameterize upper ocean mixing.

[11] The biogeochemical module of the BOGCM predicted DIC, alkalinity, oxygen and phosphate. What follows is brief description of this model: a more detailed description of the model is given by Matear [2004] and Matear and Hirst [1999]. Export production in the top $50 \mathrm{~m}$ was calculated as a function of light, phosphate, temperature and mixed layer depth. $\mathrm{CaCO}_{3}$ production was set at $8 \%$ of the export production following Yamanaka and Tajika [1996] and consistent with Trull et al. [2001a]. Below the euphotic zone, particulate organic matter was remineralized as a function of depth according to $(\mathrm{z} / 100)^{-0.9}$ following values deduced from observations [Suess, 1980] and [Martin et al., 1987]; and $\mathrm{CaCO}_{3}$ according to $\mathrm{e}^{(-\mathrm{z} / 3500)}$ following Yamanaka and Tajika [1996]. Nutrient uptake and remineralization of $\mathrm{P}: \mathrm{N}: \mathrm{C}: \mathrm{O}_{2}$ were related via the Redfield ratio of 1:16:106:-138 [Redfield et al., 1963] in and below the euphotic zone.

[12] The model was forced with daily wind stress, heat and freshwater fluxes from NCEP-R1 [Kalnay, 1996]. The model was not coupled to sea-ice model, but the effects of sea-ice on heat and freshwater fluxes were accounted for by the use of NCEP-R1 forcing that does contain sea ice. To avoid excessive model drift, sea surface temperature and salinity were restored to observed sea surface temperatures (SST) [Reynolds and Smith, 1994] and sea surface salinity [Conkright et al., 2002] every 30 days. Air-sea gas exchange of $\mathrm{CO}_{2}$ was calculated following the relationship of Wanninkhof [1992], using daily wind speed from NCEP-R1. To account for a lack of explicit sea ice, the net $\mathrm{CO}_{2}$ flux was scaled by the fraction of observed sea-ice cover, interpolated from the monthly climatological fields of Walsh [1978] and Zwally et al. [1983]. A net flux into the ocean was defined as positive and $\triangle \mathrm{pCO}_{2}$ as atmosphere minus ocean.

[13] The model was initialized with the values of preindustrial DIC and Alkalinity from GLODAP [Sabine et al., 2005] and temperature and salinity fields from the World Ocean Atlas [Conkright et al., 2002] in accordance with the protocols of the Northern Ocean Carbon Exchange Study (NOCES)/Ocean Carbon Model Intercomparison Project 3 (OCMIP3) (O. Aumont et al., NOCES Project: Interannual HOWTO, 2004, http://www.ipsl.jussieu.fr/OCMIP/time3/ simulations/NOCES/HOWTO-NOCES.html) (hereinafter referred to as Aumont et al., online document, 2004). The model was then evolved from 1837 to 2002 with observed atmospheric $\mathrm{pCO}_{2}$ values from [Enting et al., 1994] in accordance with the protocols of NOCES/OCMIP3. The 

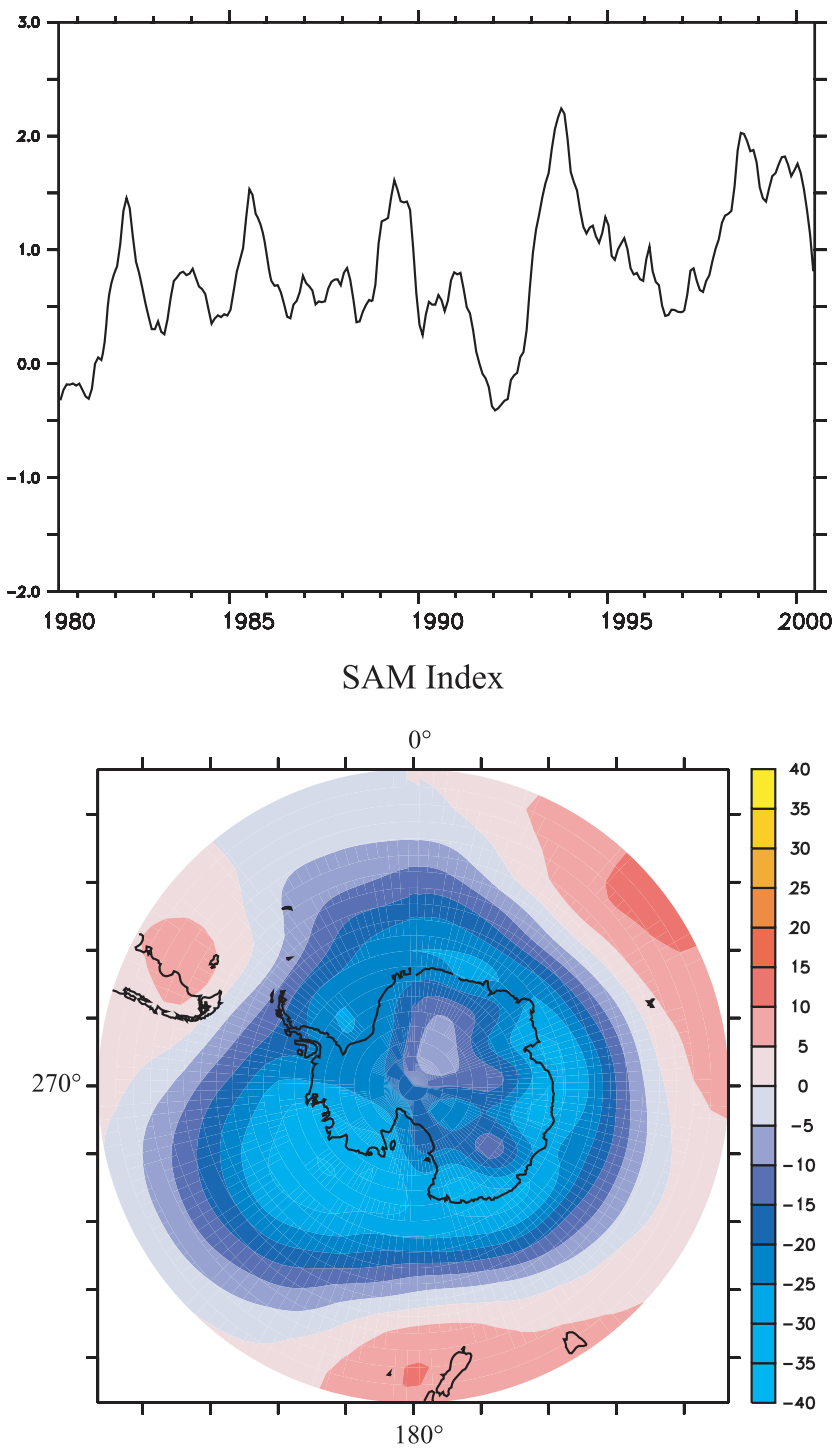

SAM Spatial Pattern

Figure 1. SAM index and spatial pattern as calculated from the NCEP-R1 $850 \mathrm{hPa}$ geopotential height anomaly.

protocols of NOCES were designed to best simulate variability in global biogeochemical ocean models on interannual to interdecadal timescales.

[14] To isolate the simulated interannual variability in the monthly averaged biogeochemical fields, we calculated for the 1980-2000 period the seasonal climatology and subtracted this from the simulated fields. The remaining nonseasonal variability was smoothed with a 12-month running-mean filter to ensure that only interannual variability was extracted.

[15] As we chose to restore sea surface temperature to [Reynolds and Smith, 1994] we cannot use this data set to validate interannual variability following Le Quéré et al. [2000]. We do not believe that validating the model at the North Atlantic Bermuda Time Series Station (BATS) nor North Pacific Hawaii Ocean Time Series (HOTS) would elucidate the processes controlling air-sea $\mathrm{CO}_{2}$ fluxes in the Southern Ocean.

\subsection{Positions of the Fronts}

[16] The Southern Ocean south of $40^{\circ} \mathrm{S}$ is made up of a series of major fronts and interfrontal zones: each of these zones has its own unique set of biogeochemical and physical properties [Trull et al., 2001b]. To facilitate our later discussion of the response of each region, the mean positions (1980-2000) of the major fronts of the Southern Ocean were identified on the basis of temperature definitions $(\theta)$. These major fronts and their definitions were the Subtropical Front (STF) $\theta<10^{\circ} \mathrm{C}$ at $150 \mathrm{~m}$ [Orsi et al., 1995], the SubAntarctic Front $\theta>4^{\circ} \mathrm{C}$ at $400 \mathrm{~m}$ [Orsi et al., 1995] and the Polar Front (PF) $\theta>2{ }^{\circ} \mathrm{C}$ at $300 \mathrm{~m}$ [Trull et al., 2001b]. These fronts separate the four major interfrontal zones of the Southern Ocean: the Subtropical Gyre (north of the STF); the SubAntarctic Zone (SAZ; between the STF and SAF); the Polar Frontal Zone (PFZ; between the SAF and PF); and the Antarctic Zone (south of the PF). These fronts and interfrontal zones are displayed on subsequent spatial maps.

\subsection{Southern Annular Mode (SAM)}

[17] The SAM was assessed in terms of the SAM index, defined as the time series of the first EOF of the $850 \mathrm{hPa}$ geopotential height anomaly. We use the NCEP-R1 reanalysis [Kalnay, 1996] to calculate the geopotential height anomaly (1980-2000) by subtracting the mean climatology between 1979 and 2000. In the calculation of the mean we neglected data prior to 1979 because it is not well validated over Antarctica [Marshall, 2002]. The SAM index was then smoothed with a 12-month running-mean filter to ensure that only interannual variability in the SAM was captured. The SAM index (1980-2000; Figure 1) showed a definite positive trend consistent with other SAM indices calculated using other techniques and data sets [Marshall, 2002]. The spatial pattern of the SAM is also displayed in Figure 1.

\subsection{Statistical Approach}

[18] To quantify the response to the SAM of the Southern Ocean air-sea $\mathrm{CO}_{2}$ flux and its components, we regressed these components against the SAM, which allowed us to estimate the response of each component per unit of change in the SAM. We also calculated the square of the corresponding correlation coefficient or $\mathrm{R}^{2}$. The $\mathrm{R}^{2}$ value quantified how much of the simulated variability was explained by the SAM $(0=$ not at all and $1=$ totally $)$. This approach is consistent with recent SAM studies [e.g., Lovenduski and Gruber, 2005; Lefebvre et al., 2004; Hall and Visbeck, 2002].

[19] To evaluate the statistical significance of our results we determined the autocorrelation length scale for the time series of 12 months translating to 20 degrees of freedom $(n=20)$. We used the single tailed t-test, to determine values of $\mathrm{R}^{2}>0.1296$ to be statistically significant at the $95 \%$ level. In subsequent analyses only the statistically significant part of the spatial maps are included. To calculate the percent of explained variance we divided the variance due to the SAM by the total variance of the interannual variability (including the SAM). Assessing the response of the Southern Ocean to the SAM we 


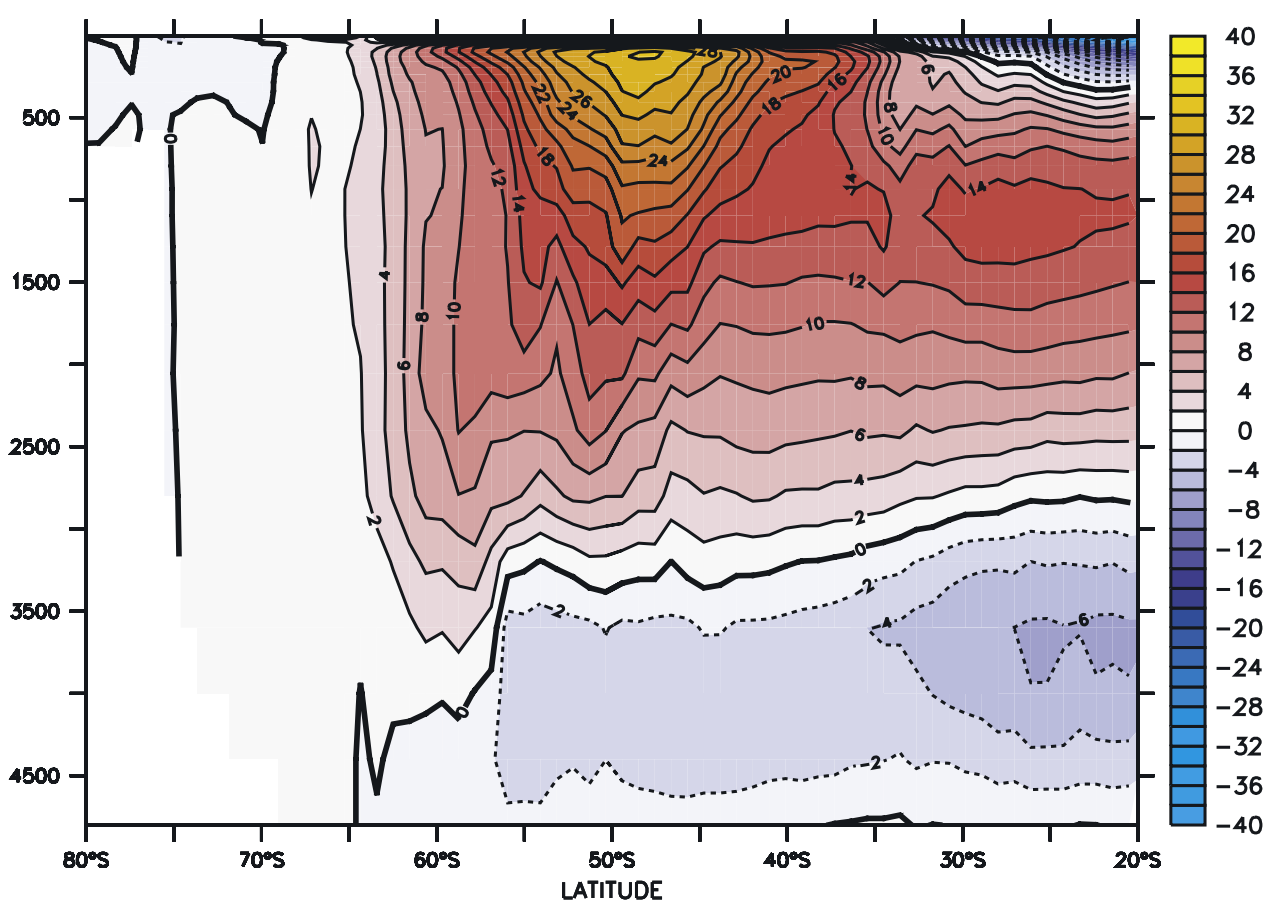

Figure 2. Annual average simulated stream function (Sv).

use the SAM index as calculated from NCEP-R1, this ensured that the response of the model was internally consistent.

\section{Results}

\subsection{Model Simulation}

[20] The Southern Ocean shows high variability in $\mathrm{CO}_{2}$ fluxes [e.g., Jabaud-Jan et al., 2004] but the paucity of data makes it impossible to directly validate large-scale interannual variability from observations. Instead we use the largescale seasonal physical and biogeochemical properties of the ocean to assess the underlying state of our ocean simulation. Although it must be emphasized that reproducing the large-scale ocean state does not guarantee a realistic simulation of interannual variability, it does provide some confidence in the preconditioning of the ocean response to

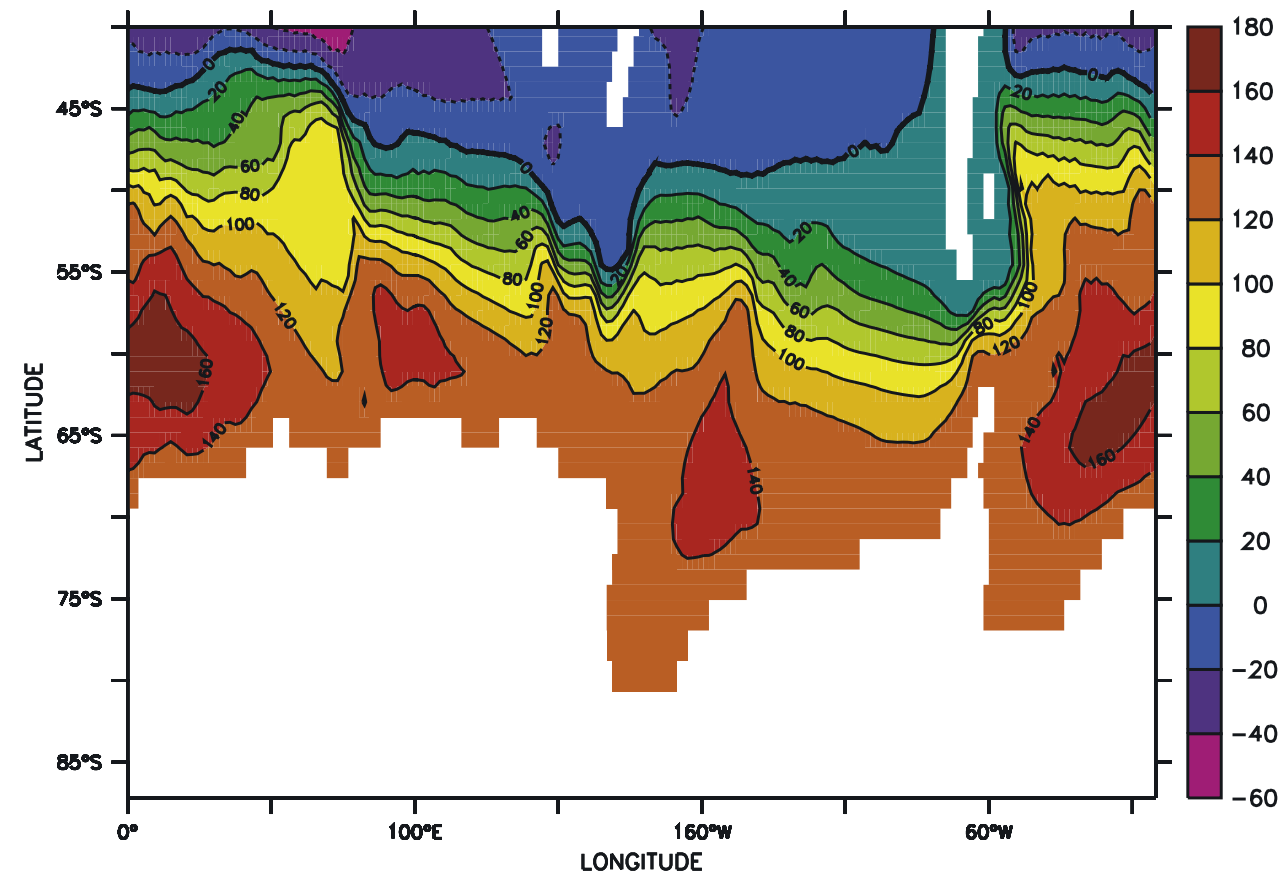

Figure 3. Annual average simulated meridional stream function (Sv; Eulerian + GM velocities) between 1980 and 2000. 

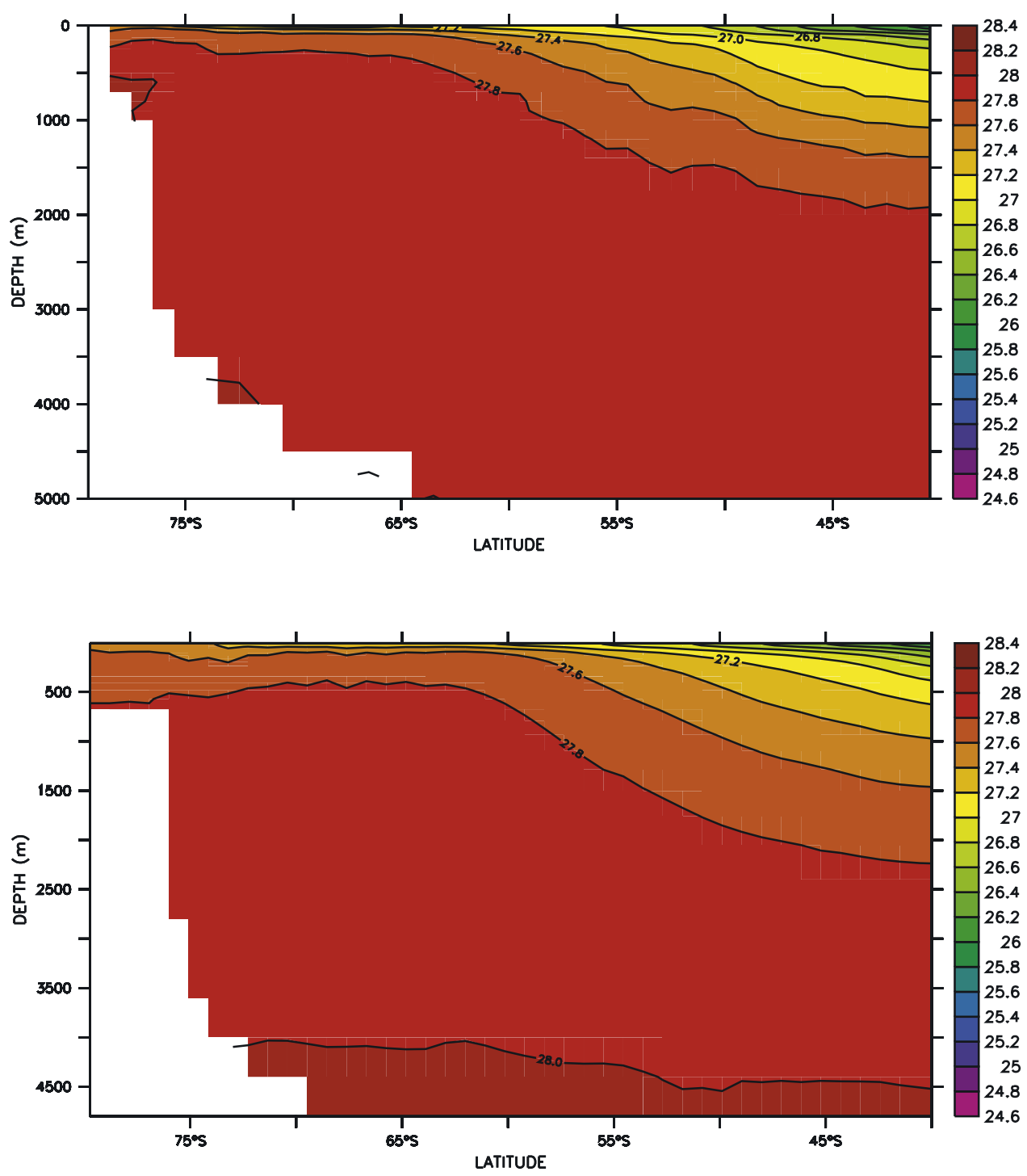

Figure 4. Density structure of the Southern Ocean: (top) density structure as calculated from the WOA [Conkright et al., 2002] and (bottom) density structure as simulated by the model and density structure as simulated by the model $\left(\mathrm{kg} / \mathrm{m}^{3}-1000\right)$.

the SAM. To assess this base state of our ocean simulation we include a comparison of the annual mean state of both the ocean dynamics and biogeochemistry with published studies.

[21] The mean barotropic stream function (Figure 2) showed an estimated Drake Passage transport for the period 1980-2000 of $131 \mathrm{~Sv}$, which was in good agreement with the observed value of $136.7 \pm 7.8 \mathrm{~Sv}$ [Cunningham et al., 2003]. The simulated Southern Ocean meridional overturning stream function (Eulerian $+\mathrm{GM}$ ) is shown in Figure 3. The value of the North Atlantic Deep Water (NADW) inflow at $30^{\circ} \mathrm{S}$ was $8 \mathrm{~Sv}$, which is lower than the estimates of 15-20 Sv published by Talley [2003]. The maximum strength of the northward flowing Antarctic Bottom Water (AABW) cell was $\sim-8 \mathrm{~Sv}$ near $23^{\circ} \mathrm{S}$ at $3500 \mathrm{~m}$, which was lower than the value reported by Ganachaud and Wunsch [2000] of $21 \pm 6 \mathrm{~Sv}$. The value of the Deacon cell was $\sim 32$ Sv lying within the range of values estimated (30-45 Sv) by Speer et al. [2000]. We note that although the ocean simulation in general showed weaker than observed values of overturning circulation, the simulated values do lie within the range of values from this current class of coarse-resolution biogeochemical ocean models [Doney et al., 2004].

[22] The zonal simulated annual mean density structure between 1980 and 2000 was compared with that calculated from the World Ocean Atlas 2001 [Conkright et al., 2002] in Figure 4. The simulated density appeared to capture well the observed Southern Ocean density structure well; the exception was the region south of $66^{\circ} \mathrm{S}$ that comprises the Weddell and Ross seas, where the upper ocean appeared to be more stratified in the simulation.

[23] The Phosphate $\left(\mathrm{PO}_{4}\right)$ and Dissolved Inorganic Carbon (DIC) (Figures 5 and 6) were also compared with those 



Figure 5. Southern Ocean phosphate fields: (top) from the WOA [Conkright et al., 2002] and (bottom) simulated $\mathrm{PO}_{4}(\mu \mathrm{Mol} / \mathrm{kg})$.

from the World Ocean Atlas 2001 [Conkright et al., 2002] and GLODAP [Sabine et al., 2005]. The zonal sections of $\mathrm{PO}_{4}$ and DIC showed reasonable agreement in the surface and upper ocean, the difference in the surface being that the location of the major fronts are shifted further south than observed, moving the lines of isonutrient concentration south. The subsurface values of DIC below $1000 \mathrm{~m}$ diverge from the observations with the exception of the region adjacent to the Antarctic continent, which showed good agreement down to $2000 \mathrm{~m} . \mathrm{PO}_{4}$ showed values exceeding those observed adjacent to continent, but showed reasonable agreement in the deep ocean. As the export production has been suggested to play an important role in the SAM response [Lovenduski and Gruber, 2005] we compared our values south of $50^{\circ} \mathrm{S}$ of $2.2 \pm 0.02 \mathrm{PgC} / \mathrm{yr}$ to those of $1.0 \pm 0.2 \mathrm{PgC} / \mathrm{yr}$ [Schlitzer, 2002] and $1.1 \pm 0.2 \mathrm{PgC} / \mathrm{yr}$ [Pollard et al., 2006]. This comparison suggested that although these values were calculated at different depths and included different remineralization profiles, the model does not appear to underestimate export production.

[24] To assess the impact of the mean state of our simulation we compared our air-sea $\mathrm{CO}_{2}$ flux (Figure 7) with the most recent observed annual mean air-sea $\mathrm{CO}_{2}$ flux of T. Takahashi et al. (Climatological mean surface $\mathrm{pCO}_{2}$ and net $\mathrm{CO}_{2}$ flux over the global oceans, manuscript in preparation, 2007) (hereinafter referred to as Takahashi et al., manuscript in preparation, 2007). We saw good agreement in both time and magnitude, this coupled with restoration to surface temperature and salinity, provided confidence that the annual mean state of the carbon cycle was well represented. In section 4 we discuss in further detail, in light of the SAM response, how the simulated distribution of DIC may impact on our results.

\subsection{Southern Ocean Fluxes and the SAM}

[25] From our simulation the standard deviation of the interannual variability for the study area (south of $40^{\circ} \mathrm{S}$ : 

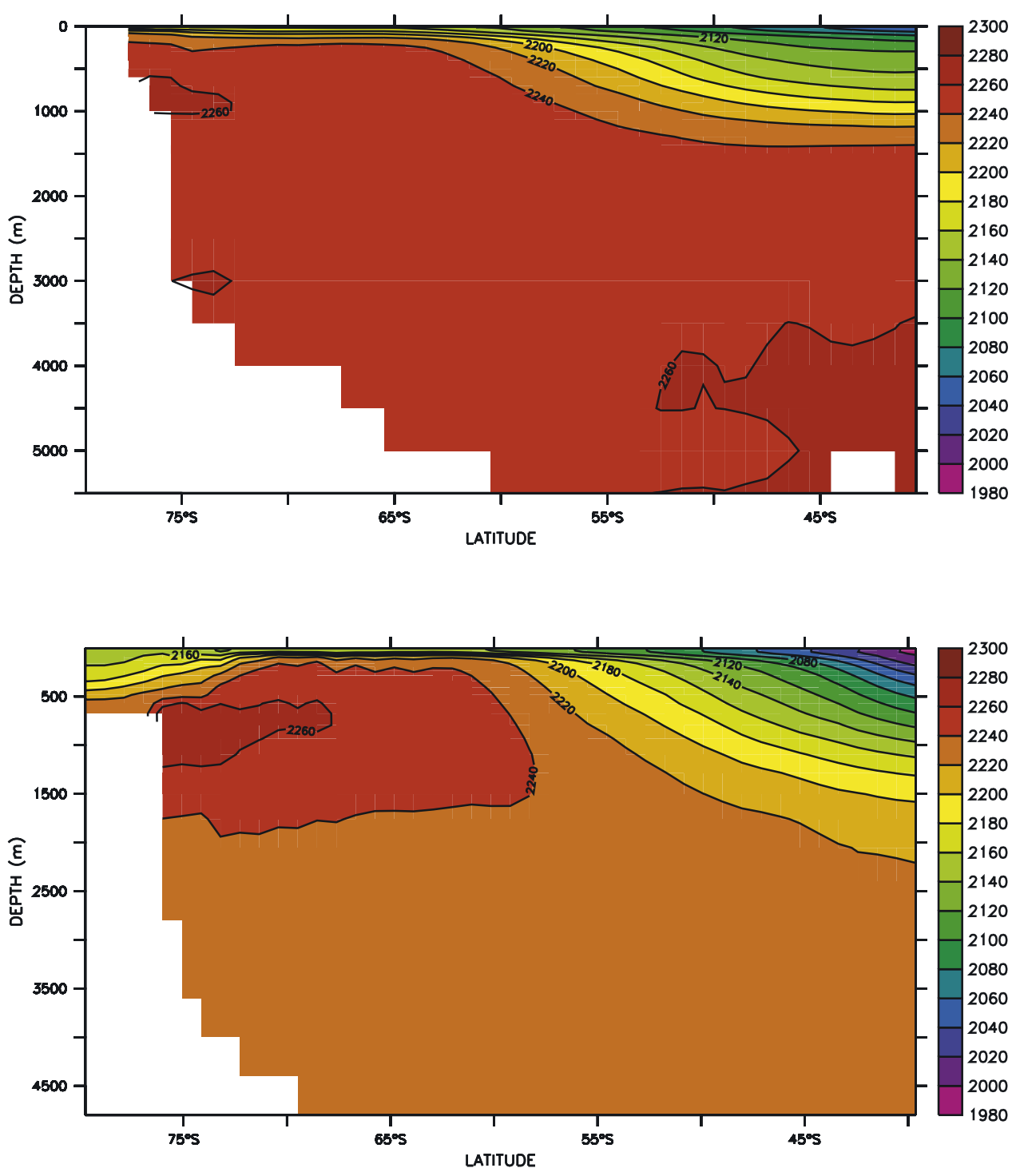

Figure 6. Southern Ocean DIC fields: (top) from the GLODAP [Sabine et al., 2005] and (bottom) simulated DIC $(\mu \mathrm{Mol} / \mathrm{kg})$.

1980-2000) was calculated as $\pm 0.16 \mathrm{PgC} / \mathrm{yr}$ and the annual mean annual mean uptake (south of $40^{\circ} \mathrm{S}$ ) of $\sim 0.8 \mathrm{PgC} / \mathrm{yr}$ between 1980-2000. The interannual variability was regressed against the SAM and the $\mathrm{R}^{2}$ values were calculated using different temporal lags. Integrating the total response of the Southern Ocean to the SAM we see a net decrease in uptake of $\mathrm{CO}_{2}$ of $0.09 \mathrm{PgC} / \mathrm{yr}$ per unit change in the SAM with no time lag and a maximum value of $0.1 \mathrm{PgC} / \mathrm{yr}$ per unit change in the SAM with a lag time lag of 2 months (Figures 8 and 9). The total integrated response of Southern Ocean airsea $\mathrm{CO}_{2}$ fluxes to the SAM was compared with the total interannual variability (Figure 10). The amount of the total interannual variance in air-sea $\mathrm{CO}_{2}$ flux explained by the SAM also increased from $36 \%$ with no time lag to $42 \%$ with the addition of this 2-month time lag (Table 1).

[26] The time lag did not significantly alter the spatial pattern of the air-sea flux response of $\mathrm{CO}_{2}$, to the SAM, it only strengthened the magnitude of the response (Figure 8). The regions north and south of the mean position of the STF showed different and opposing responses to the SAM. North of the mean position of the STF there was an increase in flux of $\mathrm{CO}_{2}$ into the ocean; south of the STF there was a decrease in the flux of $\mathrm{CO}_{2}$ into the ocean. In both of these regions the strongest and most highly correlated response was in the PFZ and SAZ of the Pacific and Indian Oceans, where the SAM response explained $21 \%$ and $22 \%$, respectively, of the interannual variance in $\mathrm{CO}_{2}$ fluxes (Table 1).

[27] The SAM can alter Southern Ocean $\mathrm{CO}_{2}$ fluxes through changes in the gas exchange coefficient $(K)$ and changes in $\triangle \mathrm{pCO}_{2}$. The response of each of these to changes in the SAM was assessed by regressing these variables against the SAM and then calculating the corresponding $\mathrm{R}^{2}$ value with a time lag of 2 months (Figure 11). 

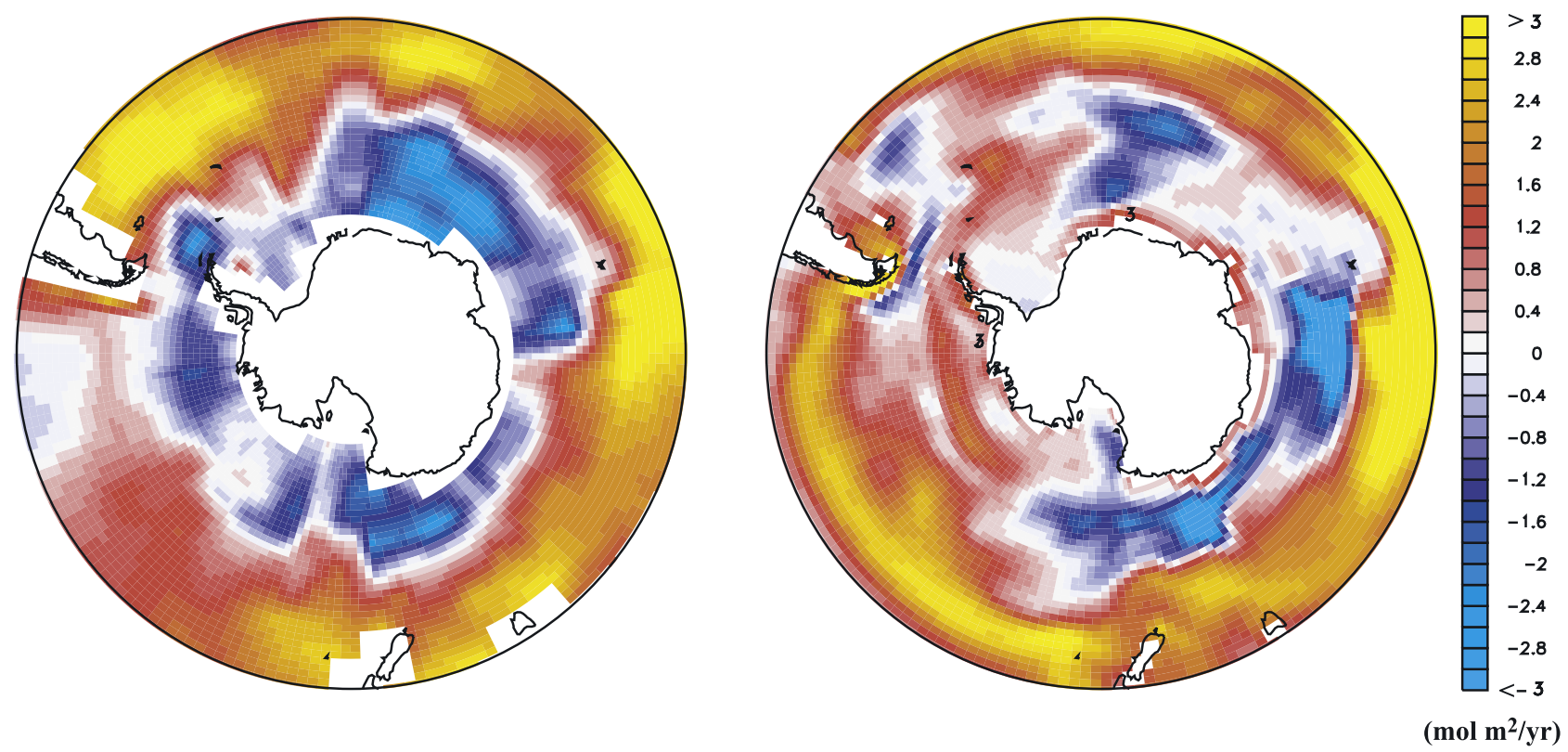

Figure 7. Comparison between the (left) observed (Takahashi et al., manuscript in preparation, 2007) and (right) simulated air-sea flux of $\mathrm{CO}_{2}$. Positive is into the ocean.

[28] A strong circumpolar response of $K$ to the SAM was evident in the region south of the STF $\left(\sim 40^{\circ} \mathrm{S}\right)$ and north of the Antarctic Divergence $\left(\sim 63^{\circ} \mathrm{S}\right)$. Between PF and SAF, $K$ was positively correlated with the SAM and up to $52 \%$ of the variance in $K$ is explain by SAM. The strongest and most highly correlated (Figure 11) response to the SAM was seen in the Indian Ocean PFZ and in the PFZ and SAZ of the Pacific Ocean, where the integrated response to the SAM explains $21 \%$ and $51 \%$ respectively of the total variance in interannual variability of $K$ (Table 2).

[29] The regression of $\Delta \mathrm{pCO}_{2}$ against the SAM (Figure 11) did not showed an obvious strong circumpolar response of $K$. Instead the Southern Ocean showed a very different circumpolar response north and south of mean position of the STF. South of the STF oceanic $\triangle \mathrm{pCO}_{2}$ showed an increase relative to atmospheric values, while north of this there was a decrease in oceanic values. The exception was the region adjacent to the Antarctic coastline, where these values do not translate to a large air-sea flux because they encompass small areas and are covered by sea ice for much of the year. The explained variance maps $\left(\mathrm{R}^{2}\right)$ of $\triangle \mathrm{pCO}_{2}$ show two semiannular rings of higher explained variance: an inner region, corresponding to the Atlantic Ocean PFZ and the Pacific PFZ; and an outer region, corresponding to the STF. The total variance in $\triangle \mathrm{pCO}_{2}$ explained by the SAM was $26 \%$ (Table 1 ). The $\triangle \mathrm{pCO}_{2}$ displays more interannual variability than was explained by the SAM.

[30] We explored how much of the total SAM response in the air-sea $\mathrm{CO}_{2}$ fluxes was driven by changes in $K$ and $\Delta \mathrm{pCO}_{2}$. The air-sea $\mathrm{CO}_{2}$ flux is given by

$$
F_{A I R-S E A}=K\left(p C O_{2 A I R}-p C O_{2 S E A}\right)=K\left(\Delta p C O_{2 A I R-S E A}\right) .
$$

[31] Equation (1) was rewritten in terms of the temporal mean $\bar{K}$ and variability $K^{\prime}$ between 1980 and 2000 .

$$
\begin{gathered}
F_{A I R-S E A}=\left(\bar{K}+K^{\prime}\right)\left(\overline{\Delta p C O_{2}}+\Delta p C O_{2}^{\prime}\right) \\
F_{A I R-S E A}=K^{\prime} \Delta p C O_{2}^{\prime}+K^{\prime} \overline{\Delta p C O_{2}}+\bar{K} \Delta p C O_{2}^{\prime}+\overline{K \Delta p C O_{2}} .
\end{gathered}
$$

[32] We calculated and regressed each of these terms of equation (3) against the SAM and then divided this by the total response of air-sea $\mathrm{CO}_{2}$ flux; this provided a means of quantifying the contribution of each term (Figure 12). The integrated response (Table 2) showed that the $\triangle \mathrm{pCO}_{2}$ response to the SAM ( $\left.\bar{K} \Delta p C O_{2}^{\prime}\right)$ contributed $67 \%$ of the total air-sea flux response: this term was strongest in the PFZ, SAZ and this STGR, particularly in the Pacific Ocean sector. The remainder of the air-sea flux variability was

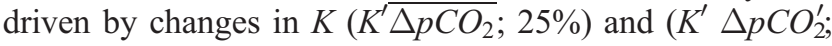
$5 \%$ ). This analysis was repeated with different temporal lags ranging from 0 to $>12$ months, the results showed that the relative importance of $K$ against $\Delta \mathrm{pCO}_{2}$ decreased as the lag increased.

\subsection{Component Analysis of $\triangle \mathrm{pCO}_{2}$ Variability}

[33] Our results showed that more than two thirds (67\%) of the total air-sea flux response was due to the changes in $\Delta \mathrm{pCO}_{2}$. In this section we attempt to understand and quantify what drives changes in $\triangle \mathrm{pCO}_{2}$ in response to the SAM. The value of $\triangle \mathrm{pCO}_{2}$ is a function of four variables: sea surface temperature (SST), sea surface salinity (SSS), TALK (Total Alkalinity) and DIC (Dissolved Inorganic Carbon), related through the standard equations of carbonate chemistry [Dickson and Goyet, 1994]. The re- 


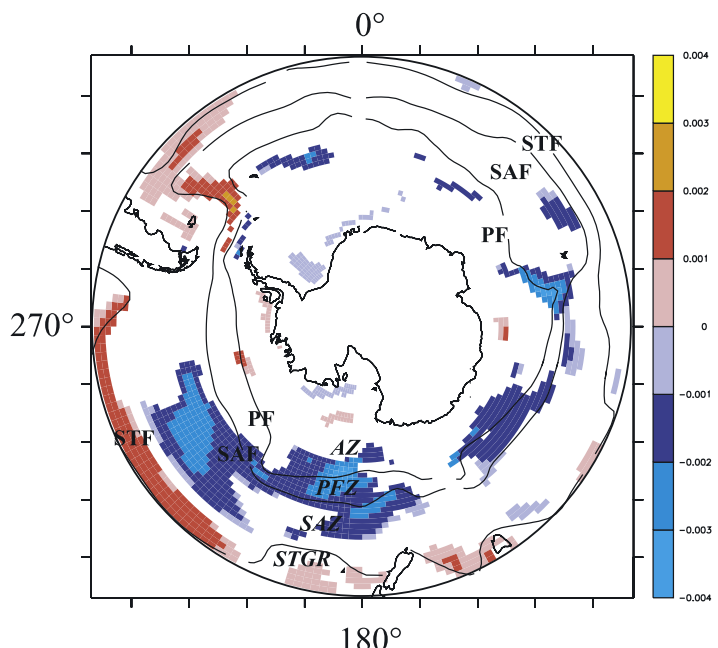

Air-Sea $\mathrm{CO}_{2}$ Flux/ SAM (no phase lag; $\mathrm{mol} / \mathrm{m}^{2} / \mathrm{d}$ )

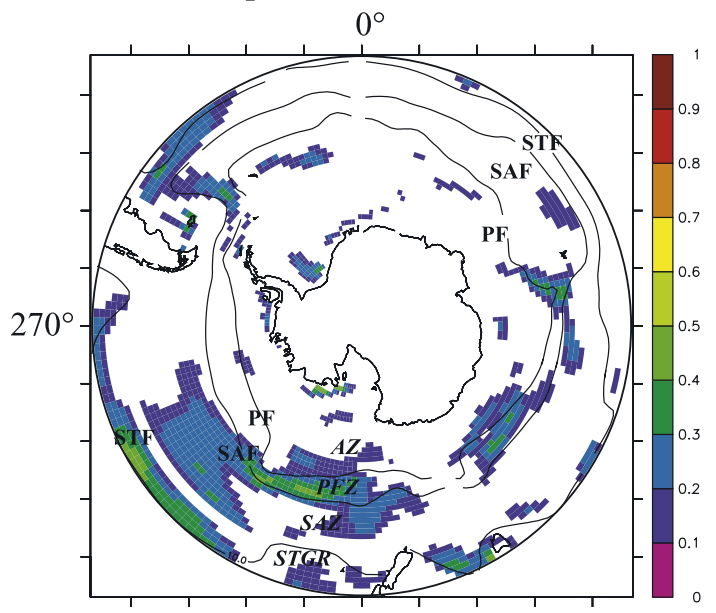

$180^{\circ}$

$\mathrm{R}^{2}$ for Air-Sea $\mathrm{CO}_{2}$ Flux (no phase lag)

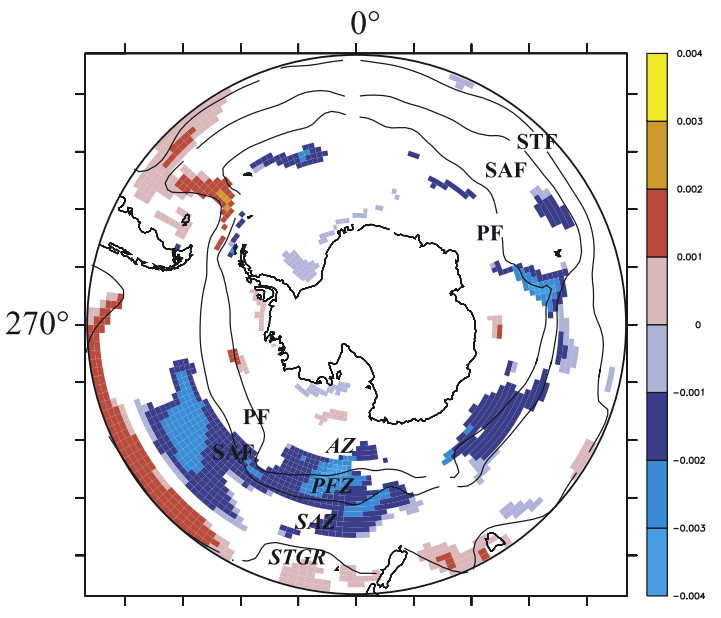

$180^{\circ}$

Air-Sea $\mathrm{CO}_{2}$ Flux/ SAM (2-month phase lag; $\mathrm{mol} / \mathrm{m}^{2} / \mathrm{d}$ ) $0^{\circ}$

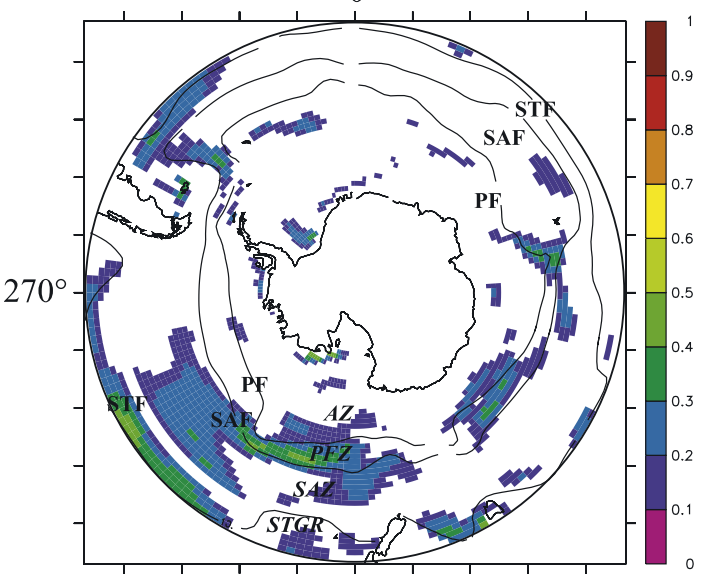

$180^{\circ}$

$\mathrm{R}^{2}$ for Air-Sea $\mathrm{CO}_{2}$ Flux (2-month phase lag)

Figure 8. (top) Regression and (bottom) $\mathrm{R}^{2}$ of the SAM Index against air-sea $\mathrm{CO}_{2}$ flux, (left) with no time lag and (right) with a 4-month time lag. Note that positive represents an increased uptake. Overlain on these maps are the mean positions of the major fronts and interfrontal zones; please refer to the text for definitions. Note that units are $\mathrm{mol} / \mathrm{m}^{2} / \mathrm{d}$ and the areas of white, in the open ocean, represent the nonstatistically significant values.

sponse of $\Delta \mathrm{pCO}_{2}$ can be written as the summation of the regression of each component onto the SAM in units of $\Delta \mathrm{pCO}_{2}(\mu \mathrm{atm})$, with a 2-month time lag, shown below:

$$
\begin{aligned}
\frac{d \Delta p C O_{2}}{d S A M}= & \frac{\partial \Delta p C O_{2}}{\partial S S T} \frac{d S S T}{d S A M}+\frac{\partial \Delta p C O_{2}}{\partial S S S} \frac{d S S S}{d S A M} \\
& +\frac{\partial \Delta p C O_{2}}{\partial T A L K} \frac{d T A L K}{d S A M}+\frac{\partial \Delta p C O_{2}}{\partial D I C} \frac{d D I C}{d S A M}
\end{aligned}
$$

[34] The component analysis, and associated spatial maps of $\Delta \mathrm{pCO}_{2}$ (Figures 13 and 14) demonstrated that DIC was the dominant term driving $\triangle \mathrm{pCO}_{2}$ variability. For a positive SAM Index, DIC showed a net increase, which drove an associated increase in $\Delta \mathrm{pCO}_{2}$ in surface waters south of the STF. SST and TALK played a significant compensating role particularly in the PFZ and SAZ by decreasing $\triangle \mathrm{pCO}_{2}$ values, partially offsetting the changes due to DIC. North of the STF, the net decrease in SST became the dominant process through solubility changes, causing a decrease in $\triangle \mathrm{pCO} 2$. The decline in DIC played a minor secondary role in this region reinforcing the decrease in $\Delta \mathrm{pCO}_{2}$. Salinity did not play a large role in driving the SAM response of airsea $\mathrm{CO}_{2}$ fluxes in any of the ocean basins. Consistent with the previous results, the component analysis was repeated with different temporal lags ranging from 0 to $>12$ months and showed that the spatial pattern did not change significantly, nor did the relative importance of each of the drivers of air-sea $\mathrm{CO}_{2}$ flux to the SAM.

\subsection{Component Analysis of DIC}

[35] South of the STF, major driver of $\Delta \mathrm{pCO}_{2}$ variability due to the SAM was identified as DIC. In this section we 


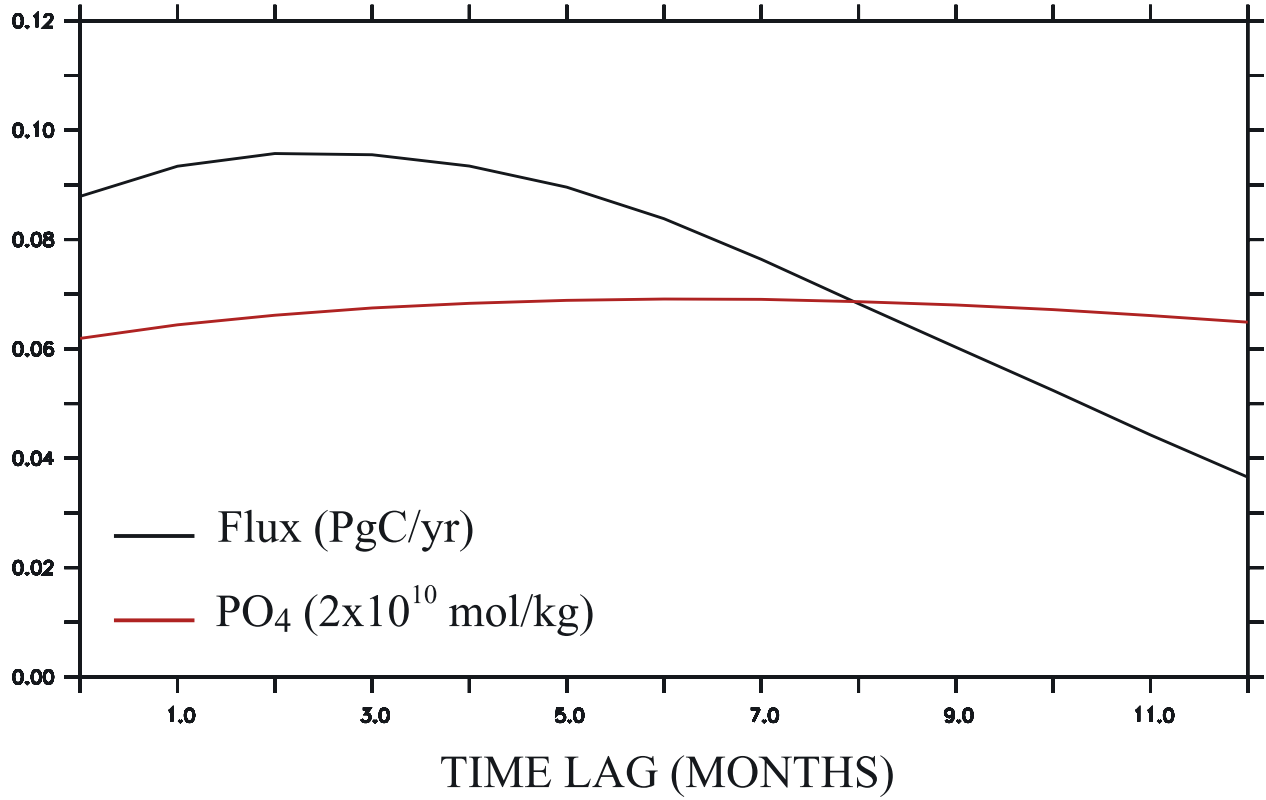

Figure 9. Response to the positive phase of the SAM, with different time lags, of interannual $\mathrm{CO}_{2}$ flux uptake (black) in the Southern Ocean south of $40^{\circ} \mathrm{S}$ and integrated phosphate (red).

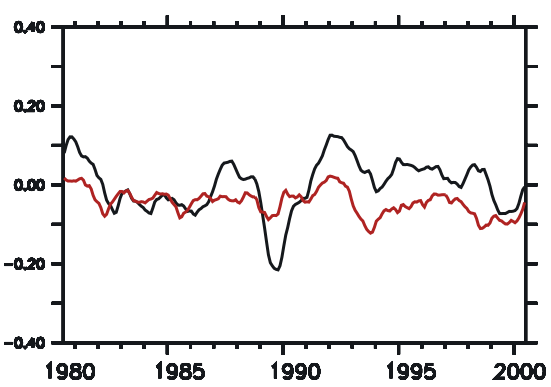

Pacific Ocean Sector (PgC/yr)

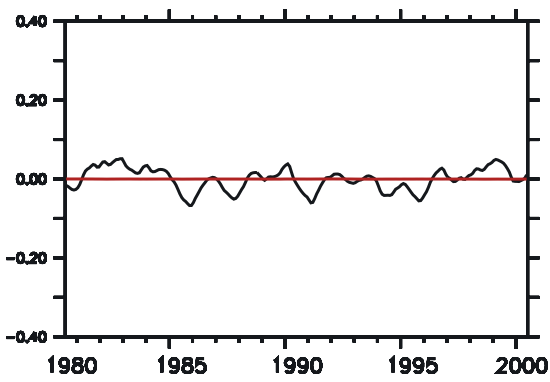

Atlantic Ocean Sector(PgC/yr)

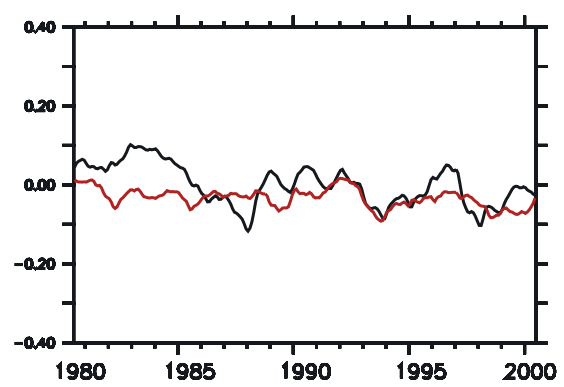

Indian Ocean Sector(PgC/yr)

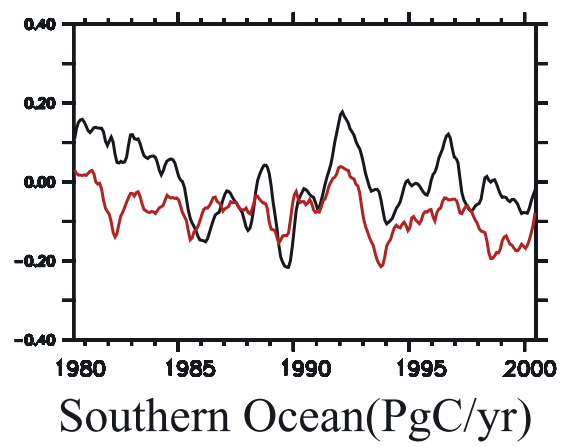

Figure 10. Simulated interannual variability in the Southern Ocean total $\mathrm{CO}_{2}$ uptake (black) and the Southern Ocean $\mathrm{CO}_{2}$ uptake explained by the SAM (red). Units are PgC/yr. 
Table 1. Percent of the Total Interannual Variability Variance Explained by the SAM South of $40^{\circ} \mathrm{S}$

\begin{tabular}{lcccc}
\hline & \multicolumn{4}{c}{ Percent Variance Explained } \\
\cline { 2 - 5 } & $\begin{array}{c}\text { Pacific } \\
\text { Ocean }\end{array}$ & $\begin{array}{c}\text { Atlantic } \\
\text { Ocean }\end{array}$ & $\begin{array}{c}\text { Indian } \\
\text { Ocean }\end{array}$ & $\begin{array}{c}\text { Southern } \\
\text { Ocean }\end{array}$ \\
\hline Gas transfer coefficient & 51 & 21 & 36 & 52 \\
$\Delta \mathrm{pCO}_{2}$ & 25 & 13 & 23 & 26 \\
Air-sea $\mathrm{CO}_{2}$ flux & 21 & 0 & 22 & 42 \\
\hline
\end{tabular}

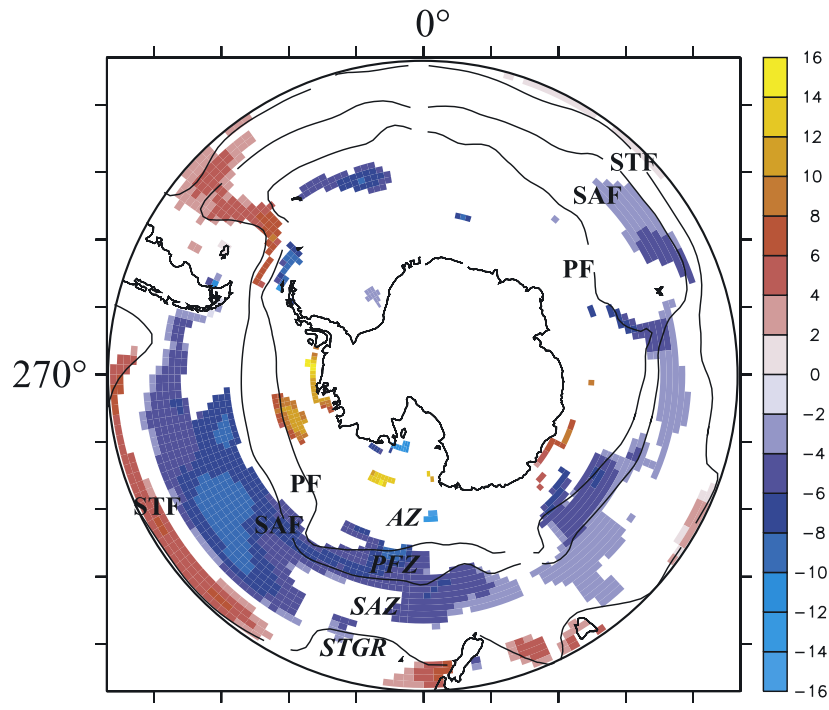

$180^{\circ}$

$\left(\mathrm{pCO}_{2}\right) / \mathrm{SAM}$

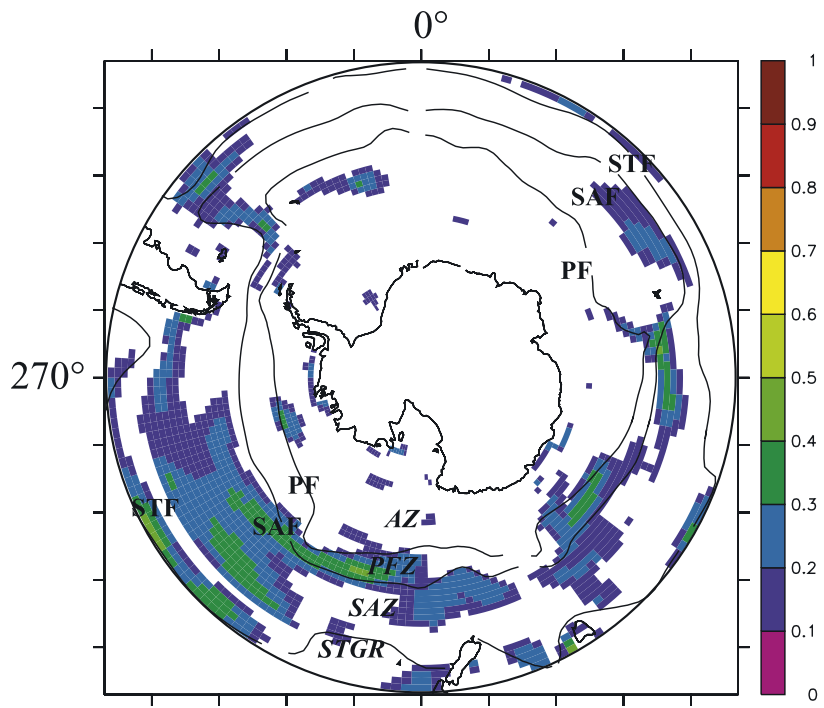

$$
\begin{gathered}
180^{\circ} \\
\mathrm{R}^{2} \text { for } \mathrm{pCO}_{2}
\end{gathered}
$$

explore what oceanic processes drove this response with a 2-month time lag.

[36] Total (SAM) DIC change over the upper grid box of the model $(10 \mathrm{~m})$ was separated into changes due to: (1) ocean physics; (2) air-sea $\mathrm{CO}_{2}$ flux; (3) freshwater dilution fluxes; and (4) export production, shown by

$$
\begin{aligned}
\frac{\partial \triangle p C \mathrm{O}_{2}}{\partial D I C} \frac{d D I C}{d S A M}= & \frac{\partial \Delta p C O_{2}}{\partial P h y s} \frac{d P h y s}{d S A M}+\frac{\partial \Delta p C O_{2}}{\partial F l u x} \frac{d F l u x}{d S A M} \\
& +\frac{\partial \Delta p C O_{2}}{\partial \text { Dilut }} \frac{d D i l u t}{d S A M}+\frac{\partial \Delta p C O_{2}}{\partial E P} \frac{d E P}{d S A M} .
\end{aligned}
$$

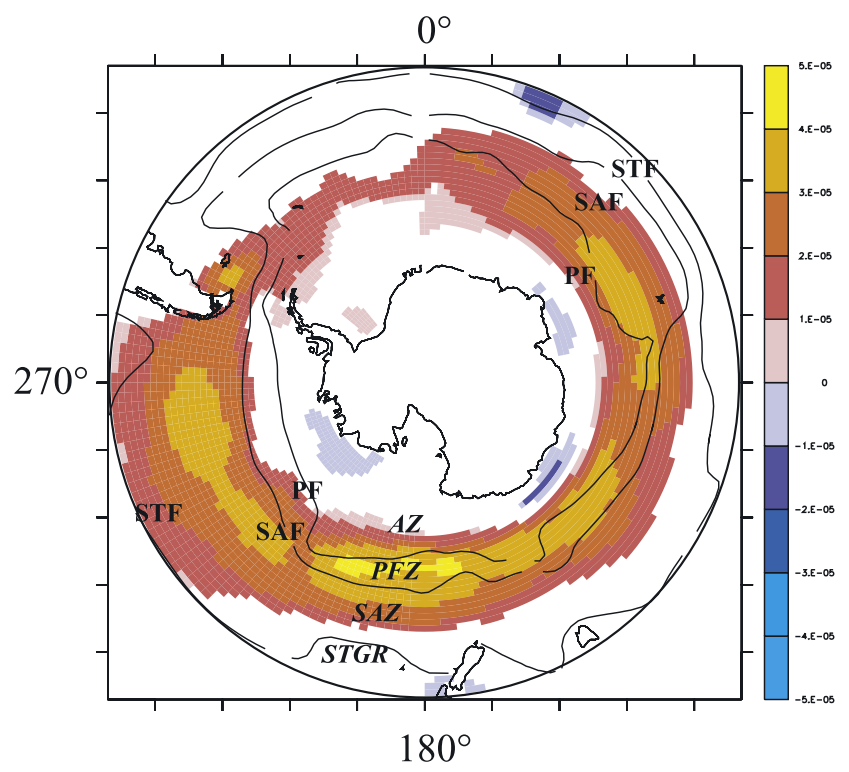

K/ SAM

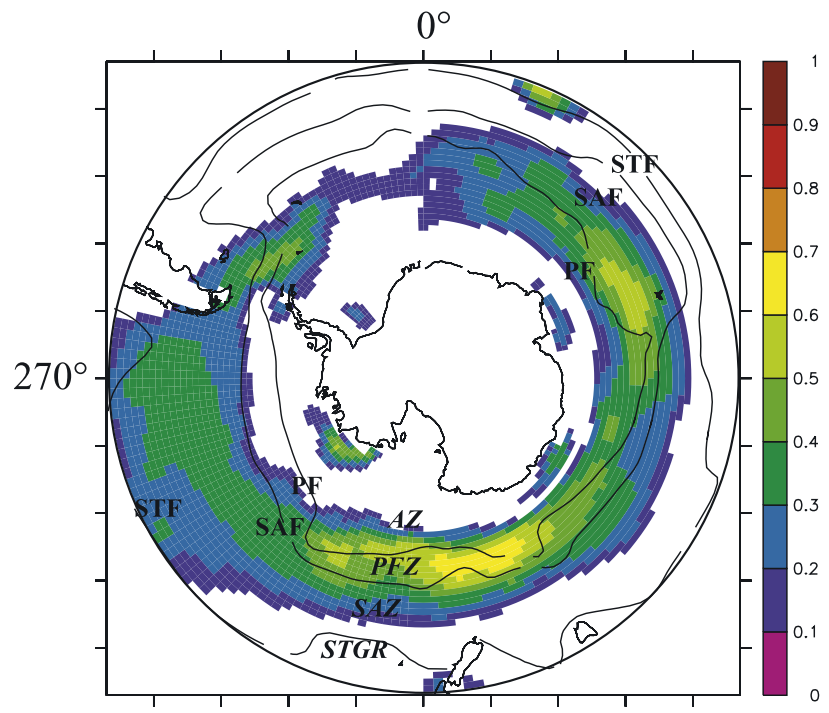

$180^{\circ}$

$\mathrm{R}^{2}$ for $K$

Figure 11. Regression and $\mathrm{R}^{2}$ of the SAM Index against $\Delta \mathrm{pCO}_{2}$ and $K$ with a 2-month time lag. Overlain on these maps are the means positions of the major fronts and interfrontal zones; please refer to the text for definitions. Note that the areas of white, in the open ocean $\left(\mathrm{R}^{2}<0.13\right)$, represent the nonstatistically significant values. 
Table 2. Percentage of the Total Integrated Southern Ocean Response of Interannual Air-Sea $\mathrm{CO}_{2}$ Flux Explained by $\bar{K}$ $\triangle p C O_{2}^{\prime}, \mathrm{K}^{\prime} \overline{\triangle p C O_{2}}$, and $\mathrm{K}^{\prime} \triangle p C O_{2}^{\prime a}$

\begin{tabular}{lcccc}
\hline & \multicolumn{4}{c}{ Percent Flux Explained } \\
\cline { 2 - 5 } & $\begin{array}{c}\text { Pacific } \\
\text { Ocean }\end{array}$ & $\begin{array}{c}\text { Indian } \\
\text { Ocean }\end{array}$ & $\begin{array}{c}\text { Atlantic } \\
\text { Ocean }\end{array}$ & $\begin{array}{c}\text { Southern } \\
\text { Ocean }\end{array}$ \\
\hline $\bar{K} \frac{\Delta p C O_{2}{ }^{\prime}}{\bar{K}^{\prime}}$ & 64 & 85 & 35 & 67 \\
$\mathrm{~K}^{\prime} \Delta p \mathrm{O}_{2}{ }^{\prime}$ & 29 & 13 & 60 & 25 \\
$\mathrm{~K}^{\prime} \Delta p C O_{2}{ }^{\prime}$ & 8 & 2 & 5 & 7 \\
\hline
\end{tabular}

${ }^{\text {a }}$ See text for explanation.

[37] The zonally integrated response, and the associated spatial maps, to the SAM of DIC and its respective components (Figures 15 and 16) demonstrated that the ocean dynamics dominated. The magnitude of the changes in DIC due to ocean dynamics increased moving northward away from the coast. The ocean physical response of DIC was partially offset by changes in air-sea $\mathrm{CO}_{2}$ fluxes, particularly in the PFZ and SAZ. Export production and freshwater dilution fluxes played no significant role in driving changes in DIC in response to the SAM. For completeness we repeated this analysis with TALK (not
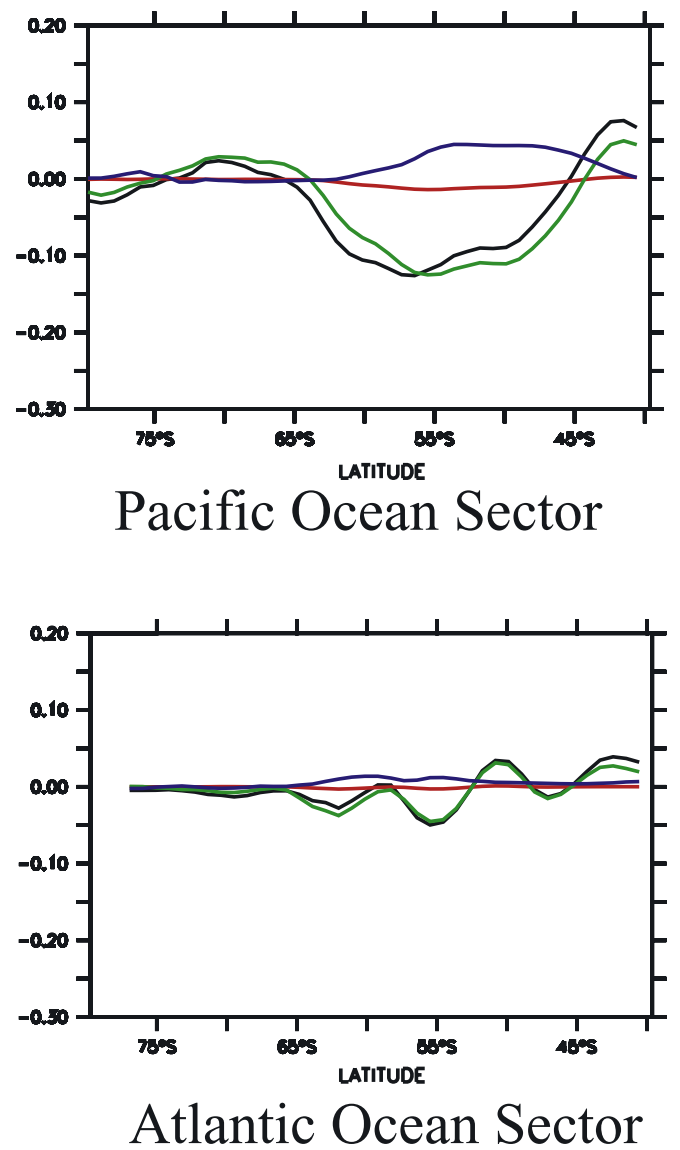

shown) and saw that ocean physics drove the changes and export production and freshwater dilution fluxes played no significant role.

[38] To demonstrate the strong link between the physical supply of DIC and air-sea $\mathrm{CO}_{2}$ fluxes we used phosphate $\mathrm{PO}_{4}$ variability as a proxy physical supply. $\mathrm{PO}_{4}$ is a good proxy for the oceanic supply of DIC as: it contains no airsea flux term; the export production response was small as the Southern Ocean is not a phosphate limited region; and it is related to DIC via fixed stoichiometric ratios. We calculated the integrated $\mathrm{PO}_{4}$ in the upper grid box of the Southern Ocean (Figure 9) and it showed that the maximum value of $\mathrm{PO}_{4}$ occurred 6 months after the SAM maximum, 4 months later than the maximum value of air-sea $\mathrm{CO}_{2}$ fluxes. The same properties that make $\mathrm{PO}_{4}$ a good proxy for physical supply explain the time lag between than DIC and $\mathrm{PO}_{4}$.

\section{Discussion and Conclusion}

[39] We simulated the Southern Ocean interannual variability by driving a global biogeochemical ocean general circulation model with the NCEP-R1 atmospheric forcing. This experiment was performed in accordance with the
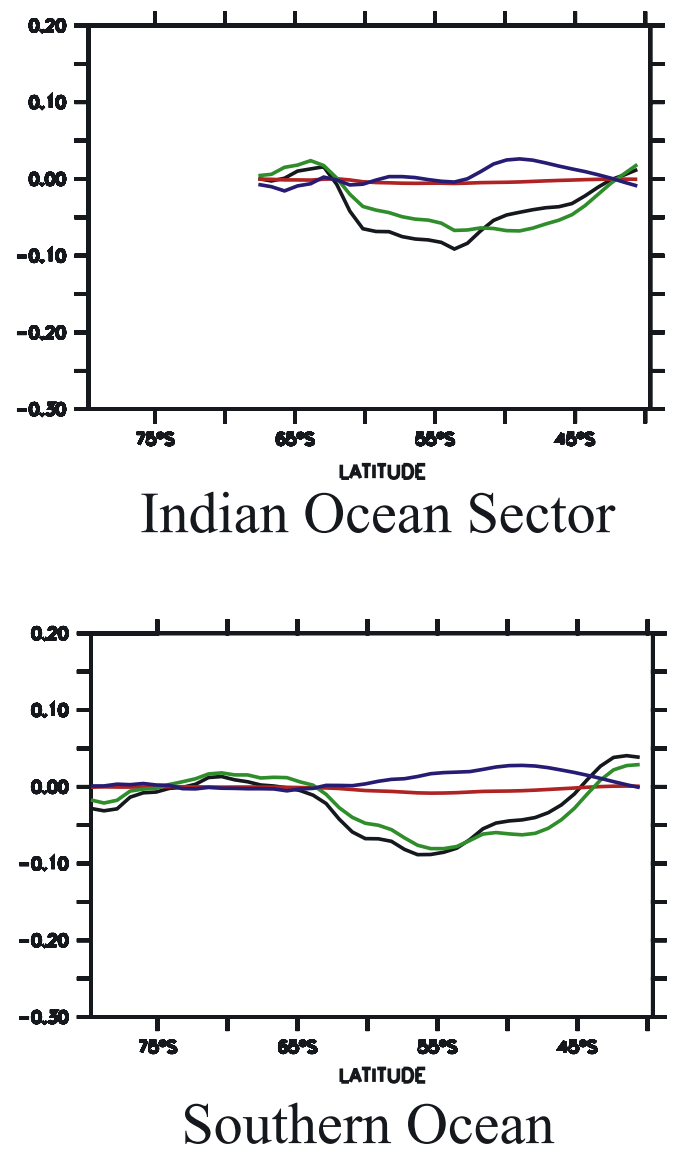

Figure 12. Zonally averaged component analysis of interannual variability of $\mathrm{CO}_{2}$ air-sea flux driven by the SAM in each of the major ocean basins: total air-sea $\mathrm{CO}_{2}$ flux response (black line) due to $\bar{K}$ $\triangle p C O_{2}^{\prime}$ (green line), $\mathrm{K}^{\prime} \overline{\Delta p C O_{2}}$ (blue line), and $\mathrm{K}^{\prime} \triangle p C O_{2}^{\prime}$ (red line). Units are $\left(\left(\mathrm{mmol} / \mathrm{m}^{2} / \mathrm{d}\right) / \triangle \mathrm{SAM}\right.$ Index) 


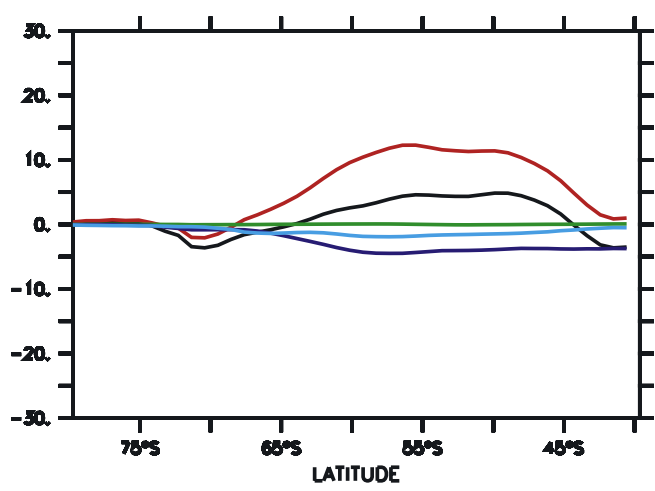

Pacific Ocean Sector

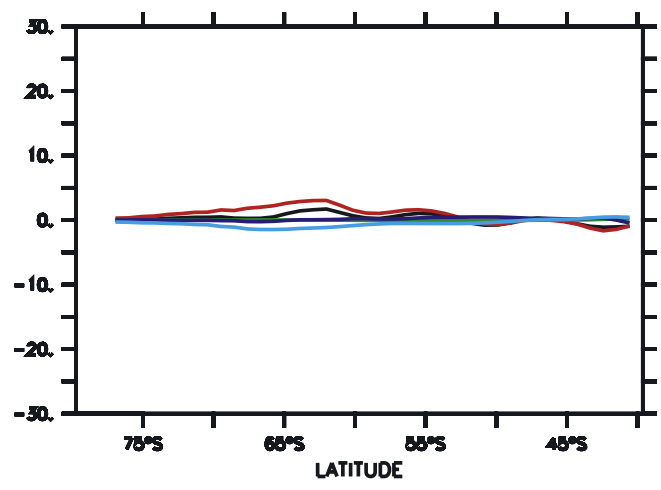

Atlantic Ocean Sector

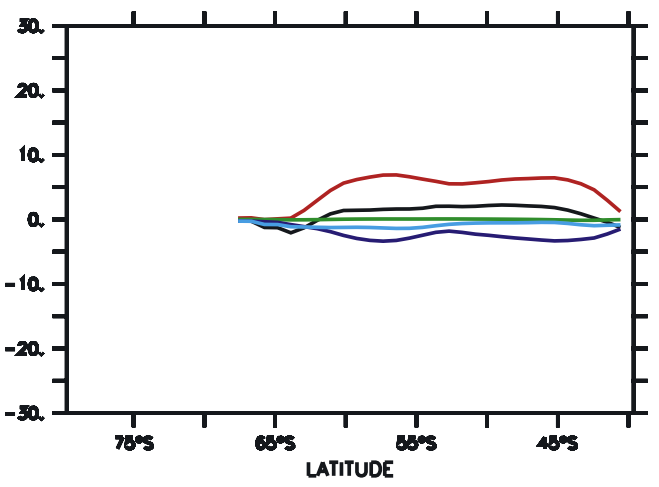

Indian Ocean Sector

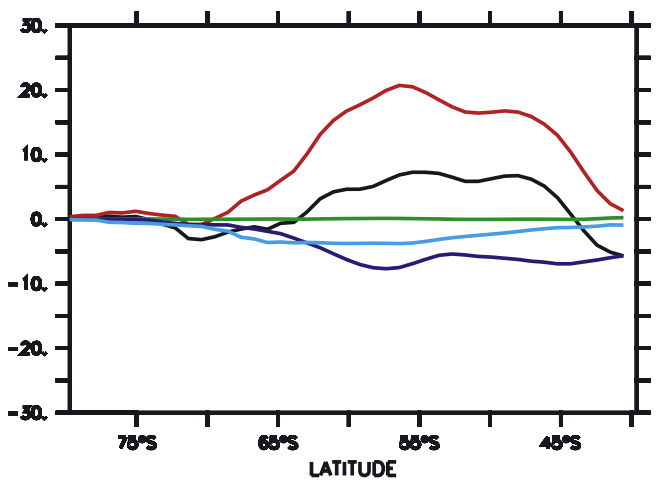

Southern Ocean

Figure 13. Zonally integrated component analysis of interannual variability of $\Delta \mathrm{pCO}_{2}$ driven by the $\mathrm{SAM}$ in each of the major ocean basins: total $\triangle \mathrm{pCO}_{2}$ (black line) and $\Delta \mathrm{pCO}_{2}$ variability due to DIC (red line), TALK (light blue line), salinity (SSS) (green line), and SST (dark blue line). All units are $1 \times 10^{7} \mu \mathrm{atm}$.

protocols of NOCES/OCMIP3 that were designed to simulate variability at interannual and longer timescales (Aumont et al., online document, 2004).

[40] We concluded that the SAM does play an important role in driving interannual variability in air-sea $\mathrm{CO}_{2}$ fluxes through the oceanic response, explaining $42 \%$ of the total interannual variance with a 2 -month time lag. In the positive phase of the SAM, the region south of the STF showed a net decrease in uptake of $\mathrm{CO}_{2}$, while north of the STF there was a net increase. While these regions did have some compensating effect, when integrated over the Southern Ocean, the region south of the STF was clearly dominant, inducing a net change in uptake in $\mathrm{CO}_{2}$ of $0.1 \mathrm{PgC} / \mathrm{yr}$ per unit change in the SAM, relative to the simulated annual mean uptake of $0.8 \mathrm{PgC} / \mathrm{yr}$ (south of $40^{\circ}$ ).

[41] Our results demonstrated that while the SAM affects both $K$ and $\Delta \mathrm{pCO}_{2}$, it was primarily changes in $\triangle \mathrm{pCO}_{2}$ (67\%) that drove the response of air-sea fluxes in the Southern Ocean. Our analysis showed these changes in $\triangle \mathrm{pCO}_{2}$ were in turn driven by changes in the concentration of DIC in Southern Ocean surface waters. South of the STF, during the positive phase of the SAM, ocean physics drove the increased supply of DIC to surface waters; the strongest response was in the SAZ. The increase in $\triangle \mathrm{pCO}_{2}$ due to the supply of DIC was partially offset by increase in SST and TALK. Neither changes in salinity, export production nor freshwater dilution fluxes played any significant role in the response of the Southern Ocean $\mathrm{CO}_{2}$ fluxes to the SAM. North of the STF during the positive time of the SAM, surface $\triangle \mathrm{pCO}_{2}$ was decreased by solubility changes due to a decrease in SST. A comparison (not shown) between the simulated SAM response of SST and that published by Lovenduski and Gruber [2005] showed good agreement both spatially and in magnitude giving further confidence in the response of SST to the SAM.

[42] Our analysis was repeated with different temporal lags ranging from no lag to $>12$ months and showed that the spatial pattern did not change significantly, nor did the relative importance of the drivers of air-sea $\mathrm{CO}_{2}$ flux response to the SAM. The only significant difference was the decrease in the relative importance of $K$ compared to $\triangle \mathrm{pCO}_{2}$ in driving the air-sea flux variability as the lag increased ( $<2$ months). 


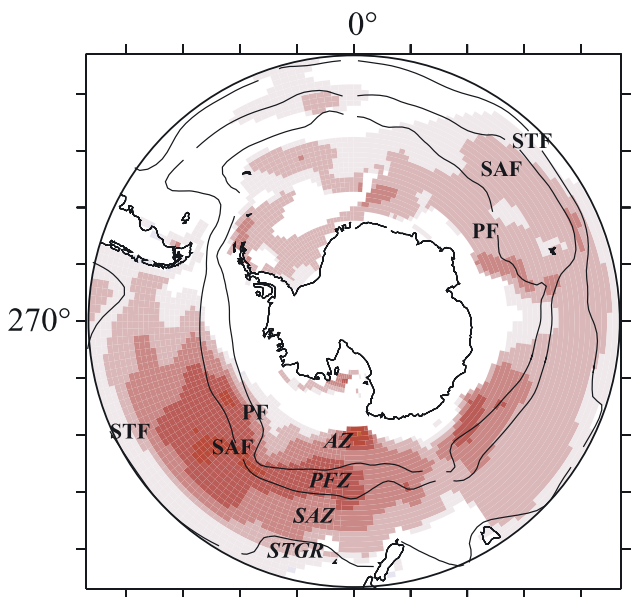

$180^{\circ}$

$\mathrm{DIC} / \mathrm{SAM}$

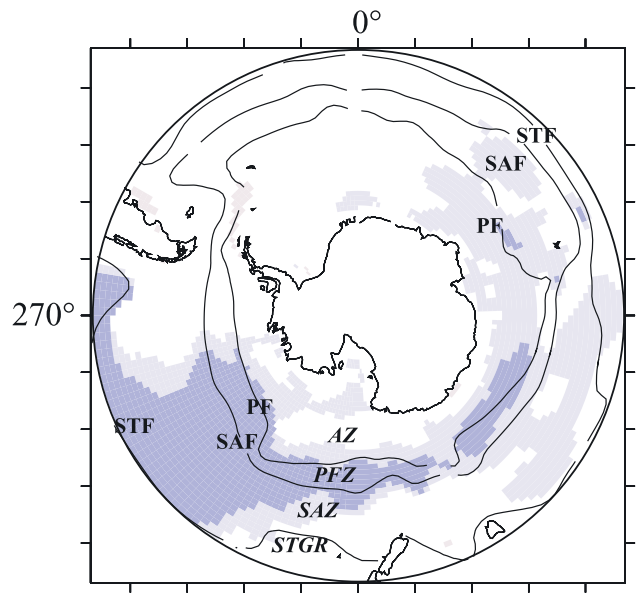

$180^{\circ}$

SST / SAM

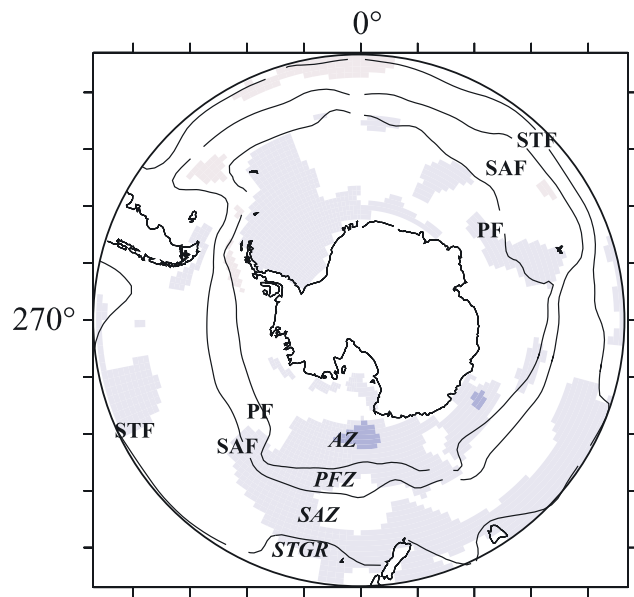

$180^{\circ}$

TALK/ SAM

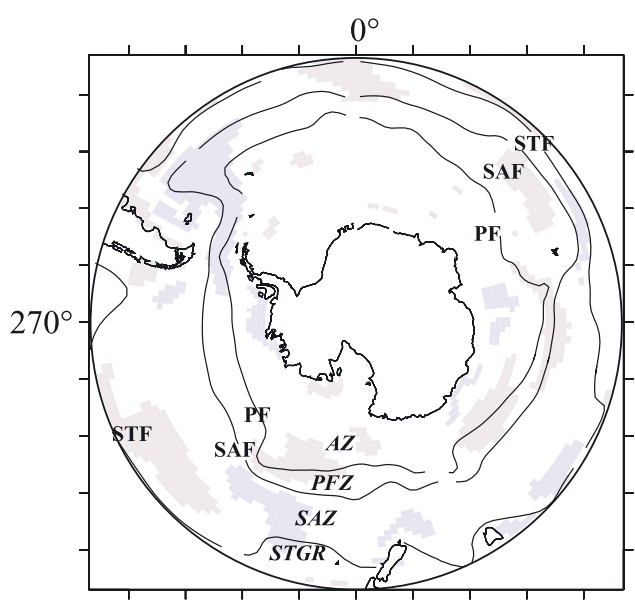

$180^{\circ}$

SSS / SAM

Figure 14. Spatial maps of the components of $\Delta \mathrm{pCO}_{2} / \Delta \mathrm{SAM}$. Overlain on these maps are the mean positions of the major fronts and interfrontal zones; please refer to the text for definitions. Note that all units are $\mu \mathrm{atm}$ and the areas of white, in the open ocean, represent the nonstatistically significant values $\left(\mathrm{R}^{2}<0.13\right)$.

[43] The 2-month time lag in the response of air-sea $\mathrm{CO}_{2}$ fluxes to the SAM reflects the accumulation of DIC in the surface water as a result of the finite response time of air-sea $\mathrm{CO}_{2}$ gas exchange. The time lag between the maximum in $\mathrm{CO}_{2}$ fluxes and the oceanic supply of DIC was due to the finite time taken for ocean physics to respond to a change in the SAM and time taken to erase the accumulation of DIC in the upper ocean. In this way the ocean can be considered to have a memory of previous events and maybe preconditioned to other drivers of interannual variability. We note that the length of the time lags determined may are also a function of the ocean physics and biogeochemistry in our model; therefore it would be of value to repeat our analysis using other ocean biogeochemical models to explore its sensitivity to differing simulations.

[44] The responses of $\Delta \mathrm{pCO}_{2}$ and $K$ to the SAM were spatially and temporally very different. $K$ showed the highest correlation with wind speed with no time lag, while the response of $\triangle \mathrm{pCO}_{2}$ was spatially varying with a clear time lag with the SAM maximum. The $\triangle \mathrm{pCO}_{2}$ response reflects the different spatial and temporal response in each of the components that drive changes in $\Delta \mathrm{pCO}_{2}$, i.e., SST, SSS, TALK and DIC to the atmospheric forcing and associated ocean circulation changes.

[45] The coarse-resolution model used in this study was not able to perfectly reproduce the limited annual mean observations of DIC and $\mathrm{PO}_{4}$ that exist in the Southern Ocean, but did show good agreement with the observed annual mean air-sea flux of Takahashi et al. (manuscript in preparation, 2007). We do not believe that these limitations in the deep ocean significantly impacted on our results because: (1) the SAM-driven increased upwelling occurred in the divergence region where the model showed reasonable agreement with observed values of DIC (above $2000 \mathrm{~m}$ ); and (2) any change in the vertical mixing occurring in the SAZ or PFZ occurred in regions where DIC and 


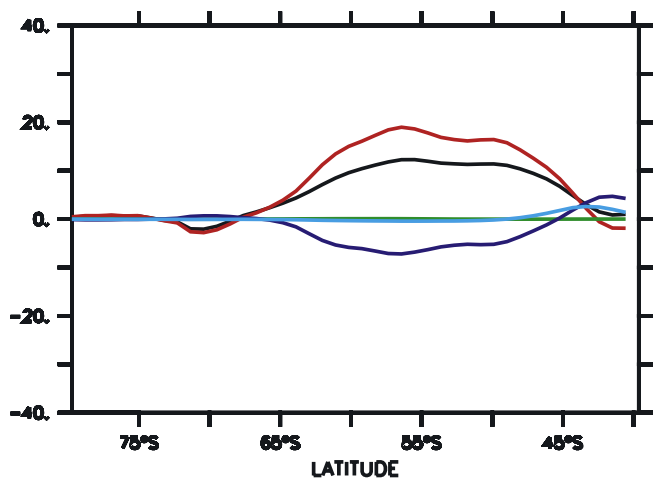

Pacific Ocean Sector

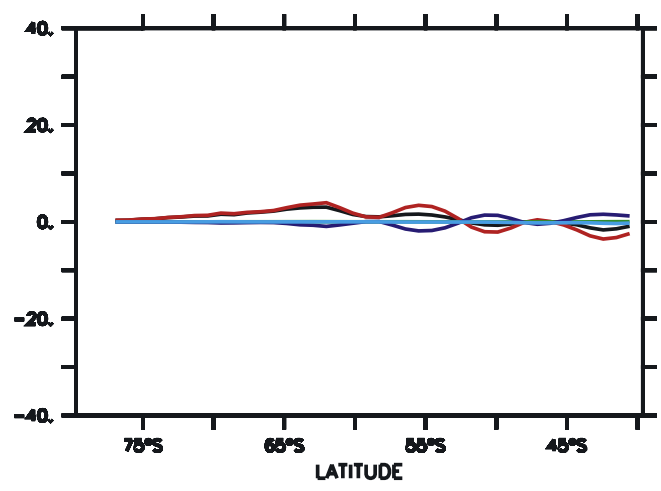

Atlantic Ocean Sector



Indian Ocean Sector

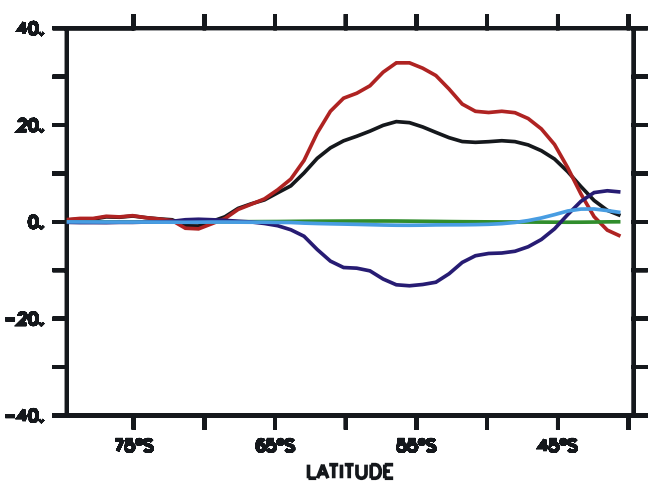

Southern Ocean

Figure 15. Zonally integrated component analysis of interannual variability of DIC driven by the SAM in each of the major ocean basins: total DIC (black line) and DIC response due to ocean physics (red line), air-sea flux (dark blue), dilution (green line), and export production (light blue line). Units are all $1 \times 10^{7} \mu \mathrm{atm}$.

density were well represented, certainly at depths well in excess of observed mixed layer depths [Trull et al., 2001b].

[46] Quantifying the importance of the SAM in driving air-sea $\mathrm{CO}_{2}$ flux variability allowed us to qualitatively compare our results to predictions made by Hall and Visbeck [2002] and Lovenduski and Gruber [2005] on the role of the SAM in driving variability. To compare our results with Lovenduski and Gruber [2005] we recalculated the explained variance with no time lag and with only the seasonal cycle removed (i.e., interannual + intraseasonal). The result was a reduction in the explained variance from $36 \%$ to 16\%; consistent with Hall and Visbeck [2002] who suggested the oceanic response to the SAM would be on interannual and longer timescales. This recalculated value $(16 \%)$ is in agreement with the 'moderate' response of airsea $\mathrm{CO}_{2}$ fluxes to the SAM as speculated by Lovenduski and Gruber [2005]. The inclusion of the 2-month time lag and exploring only the interannual-variability-only response more than doubled the explained variance (42\%); in agreement with the predictions of Hall and Visbeck [2002] of a net decrease in $\mathrm{CO}_{2}$ uptake in response to the positive SAM. These results suggest that the differences between the studies of the Hall and Visbeck [2002] and Lovenduski and Gruber [2005] can be reconciled.

[47] Our simulation showed that while export production did play a role by reducing ocean $\mathrm{pCO}_{2}$ in response to the positive time of the SAM, it had little impact on total response of the air-sea $\mathrm{CO}_{2}$ flux relative to the role DIC. As this relationship between surface DIC concentration and export production may have been biased by not including Fe (Iron) in the model we explored this question by assuming maximum growing conditions and using the observed $\mathrm{C}_{\text {SEQUESTERED }}: \mathrm{Fe}_{\mathrm{ADDED}}$ ratios of $3.3 \times 10^{3}$ from [Buesseler et al., 2004] and the observed range of ACC deep-water Fe concentrations $0.4 \mathrm{nM}$ to $2.8 \mathrm{nM}$ [Löscher et al., 1997]. This simple calculation showed that it was not possible through changes in the supply of $\mathrm{Fe}$ through upwelling or entrainment from below the mixed layer to generate the magnitude of export production that could significantly compensate the effect of DIC supply. Despite the fact that the profiles of Fe and DIC diverge with depth, even if the response of DIC to the SAM was doubled to be twice as large as our response, insufficient $\mathrm{Fe}$ exists to counter the DIC supply to the upper ocean. We concluded 


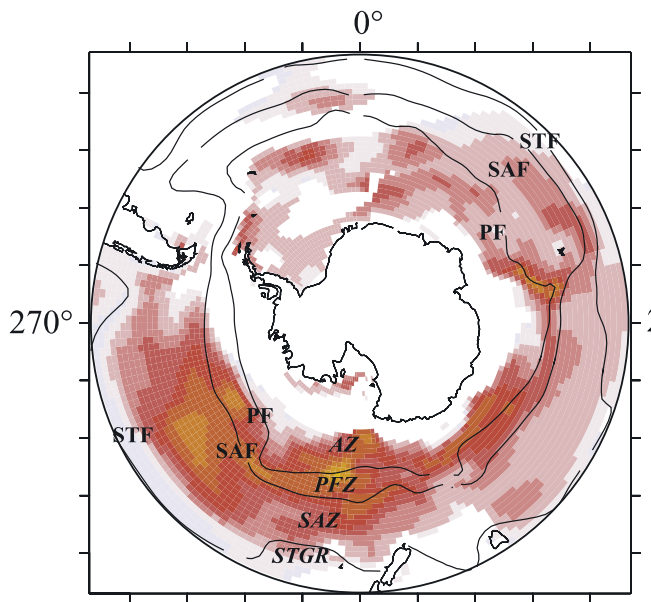

$180^{\circ}$

DIC(Ocean Circulation)/ SAM

$0^{\circ}$

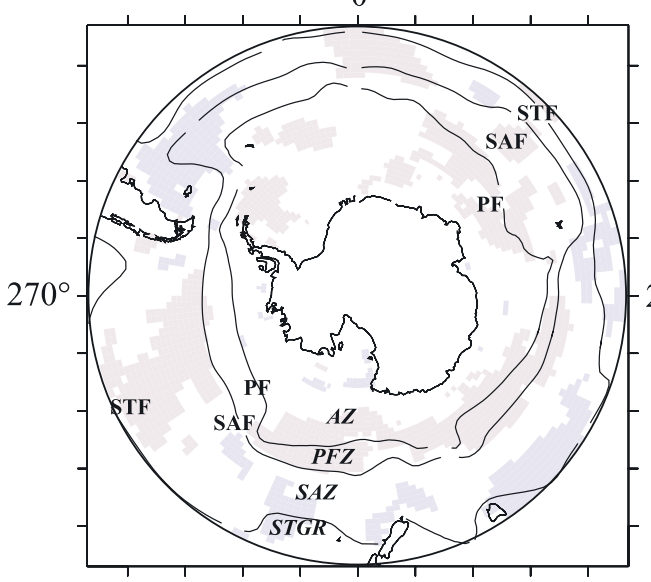

$180^{\circ}$

DIC(Virtual Flux)/ SAM

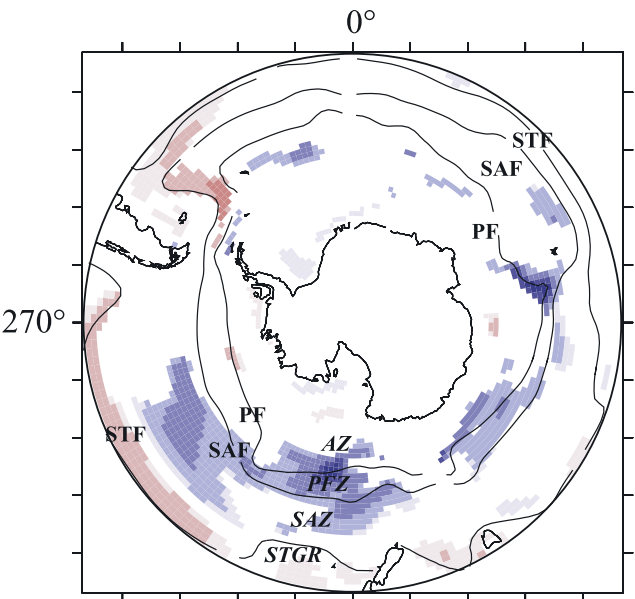

$180^{\circ}$

DIC(Air-sea Flux)/ SAM

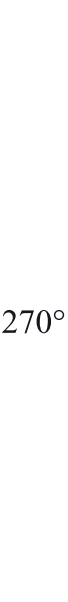

$270^{\circ}$

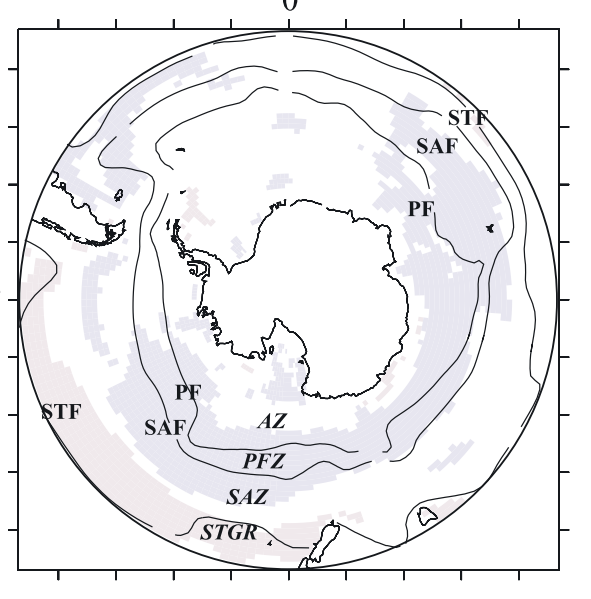

$180^{\circ}$

DIC(Export Production)/ SAM

Figure 16. Spatial maps of the components of the $\Delta \mathrm{DIC} / \triangle \mathrm{SAM}$. Overlain on these maps are the mean positions of the major fronts and interfrontal zones; please refer to the text for definitions. Note that all units are $\mu \mathrm{atm}$ and the areas of white, in the open ocean, represent the nonstatistically significant values $\left(\mathrm{R}^{2}<0.13\right)$.

therefore that the absence of Fe, although desirable in future studies, did not significantly bias our results.

[48] This model clearly does not capture high-latitude vertical stratification changes that are predicted to occur in the future [Sarmiento et al., 2004b]. Vertical stratification could have a significant influence on future $\mathrm{CO}_{2}$ fluxes if DIC supply by upwelling is, in fact, the dominant mechanism of interannual variability. Without accounting for change in vertical stratification, this model suggests that with a more positive SAM in the future, $\mathrm{CO}_{2}$ flux into the Southern Ocean will be decreased.

[49] Acknowledgments. The authors would like to thank Nicolas Metzl, Corinne LeQuéré, and two anonymous reviewers that have added value to this manuscript with their comments. This research received support from the Australian Commonwealth Cooperative Research Program and the European Integrated Project CARBOOCEAN 511176.

\section{References}

Buesseler, K. O., J. E. Andrew, S. M. Pike, and M. A. Charette (2004), The effects of iron fertilization on carbon sequestration in the Southern Ocean, Science, 304, 414-417.

Cai, W., P. Whetton, and D. J. Karoly (2003), The response of the Antarctic Oscillation to increasing and stabilized $\mathrm{CO}_{2}$, J. Clim., 10, 1525-1538.

Chen, D., L. M. Rothestein, and A. J. Busalacchi (1994), A hybrid vertical mixing scheme and its application to tropical ocean models, J. Phys. Oceanogr., 24, 2156-2179.

Conkright, M. E., et al. (2002), World Ocean Database 2001: Objective analyses, data statistics and figures, edited by S. Levitus, 17 pp., Natl. Oceanic and Atmos. Admin., Silver Spring, Md.

Cunningham, S. A., S. G. Alderson, B. A. King, and M. A. Brandon (2003), Transport and variability of the Antarctic Circumpolar Current in Drake Passage, J. Geophys. Res., 108(C5), 8084, doi:10.1029/2001JC001147.

Dickson, A. G., and C. Goyet (1994), Handbook of methods for the analysis of the various parameters of the carbon dioxide system in sea water, $O R N L / C D I A C-74$, U. S. Dep. of Energy, Washington, D. C.

Doney, S. C., et al. (2004), Evaluating global ocean carbon models: The importance of realistic physics, Global Biogeochem. Cycles, 18, GB3017, doi:10.1029/2003GB002150. 
Enting, I. G., M. L. Wigley, and M. Heimann (1994), Future emissions and concentrations of carbon dioxide: Key ocean/atmosphere/land analyses, 118 pp., Tech. Pap. 31, Div. of Atmos. Res., Commonw. Sci. And Ind. Res. Org., Melbourne, Victoria, Australia.

Ganachaud, A., and C. Wunsch (2000), Improved estimates of global ocean circulation, heat transport and mixing from hydrographic data, Nature, $408,453-456$

Gent, P. R., and J. C. McWilliams (1990), isopycnal mixing in ocean circulation models, J. Phys. Oceanogr., 20, 150-155.

Gong, D., and S. Wang (1999), Definition of the Antarctic oscillation index, Geophys. Res. Lett., 26, 459-462.

Gruber, N., C. D. Keeling, and N. R. Bates (2002), Interannual variability in the North Atlantic Ocean carbon sink, Science, 298, 2374-2378.

Hall, A., and M. Visbeck (2002), Synchronous variability in the Southern Hemisphere atmosphere, sea ice, and ocean resulting from the annular mode, J. Clim., 15, 3043-3057.

Jabaud-Jan, A., N. Metzl, C. Brunet, A. Poisson, and B. Schauer (2004), Interannual variability of the carbon dioxide system in the southern Indian Ocean $\left(20^{\circ} \mathrm{S}-60^{\circ} \mathrm{S}\right)$ : The impact of a warm anomaly in the austral summer 1998, Global Biogeochem. Cycles, 18, GB1042, doi:10.1029/ 2002GB002017.

Kalnay, E. (1996), The NCEP/NCAR 40-year reanalysis project, Bull. Am. Meteorol. Soc., 77, 437-470.

Kushner, P. J., I. M. Held, and T. L. Delworth (2001), Southern Hemisphere atmospheric circulation response to global warming, J. Clim., 14, 2238 2249

Lefebvre, W., H. Goosse, R. Timmerman, and T. Fichefet (2004), Influence of the Southern Annular Mode on the sea-ice system, J. Geophys. Res., 109, C09005, doi:10.1029/2004JC002403.

Le Quéré, C., J. C. Orr, P. Monfray, and O. Aumont (2000), Interannual variability of the oceanic sink of $\mathrm{CO}_{2}$ from 1979 through 1997, Global Biogeochem. Cycles, 14, 1247-1265.

Lenton, A., R. J. Matear, and B. Tilbrook (2006), Design of an observational strategy for quantifying the Southern Ocean uptake of $\mathrm{CO}_{2}$, Global Biogeochem. Cycles, 20, GB4010, doi:10.1029/2005GB002620.

Löscher, B. M., H. J. W. De Barr, J. T. M. De Jong, C. Veth, and F. Dehairs (1997), The distribution of Fe in the Antarctic Circumpolar Current, Deep Sea Res., Part II, 44, 143-187.

Louanchi, F., and M. Hoppema (2000), Interannual variations of the Antarctic Ocean $\mathrm{CO}_{2}$ uptake from 1986 to 1994, Mar. Chem., 72, 103-114.

Louanchi, F., M. Hoppema, D. C. E. Bakker, A. Poisson, M. H. C. Stoll, H. J. W. De Baar, B. Schauer, and D. Wolf-Gladrow (1999), Modelled and observed sea surface $\mathrm{fCO}_{2}$ in the southern ocean: A comparative study, Tellus, Ser. B, 51, 541-559.

Lovenduski, N. S., and N. Gruber (2005), Impact of the Southern Annular Mode on Southern Ocean circulation and biology, Geophys. Res. Lett., 32, L11603, doi:10.1029/2005GL022727.

Marshall, G. J. (2002), Trends in Antarctic geopotential height and temperature: A comparison between radiosonde and NCEP-NCAR reanalysis, J. Clim., 15, 659-674.

Martin, J. H., G. A. Knauer, D. M. Karl, and W. W. Broenkow (1987), VERTEX: Carbon cycling in the northeast Pacific, Deep Sea Res., 34, $267-286$

Matear, R. J. (2004), Ocean carbon cycle in a changing climate: Climate change detection, in The Ocean Carbon Cycle and Climate, edited by M. Follows, and T. Oguz, pp. 297-315, Springer, New York.

Matear, R. J., and A. C. Hirst (1999), Climate change feedback on the future oceanic $\mathrm{CO}_{2}$ uptake, Tellus, Ser. B, 51, 722-733.

McKinley, G. A., C. Rodenbeck, M. Gloor, S. Houweling, and M. Heimann (2004), Pacific dominance to global air-sea $\mathrm{CO}_{2}$ flux variability: A novel atmospheric inversion agrees with ocean models, Geophys. Res. Lett., 31, L22308, doi:10.1029/2004GL021069.

Metzl, N., A. Poisson, F. Louanchi, C. Brunet, B. Schauer, and B. Bres (1995), Spatio-temporal distributions of air-sea fluxes of $\mathrm{CO}_{2}$ in the Indian and Antarctic Oceans: A first step, Tellus, Ser. B, 47, 56-69.

Metzl, N., B. Tilbrook, and A. Poisson (1999), The annual $\mathrm{fCO}_{2}$ cycle and the air-sea $\mathrm{CO}_{2}$ flux in the sub-Antarctic Ocean, Tellus, Ser. B, 51, 849-861.

Metzl, N., C. Brunet, A. Jabaud-Jan, A. Poisson, and B. Schauer (2006), Summer and winter air-sea $\mathrm{CO}_{2}$ fluxes in the Southern Ocean, Deep Sea Res., Part II, 53, 1548-1563.

Oke, P., and M. H. England (2004), Oceanic response to changes in the latitude of the Southern Hemisphere subpolar westerly winds, J. Clim. $17,1040-1054$

Orsi, A. H., T. Whitworth, and W. D. Nowlin (1995), On the meridional extent and fronts of the Antarctic Circumpolar Current, Deep Sea Res., Part I, 42, 641-673.

Pacanowski, R. C., and S. M. Griffies (1999), The MOM 3 Manual, Geophys. Fluid Dyn. Lab., Princeton, N. J.
Pollard, R., P. Tréguer, and J. Read (2006), Quantifying nutrient supply to the Southern Ocean, J. Geophys. Res., 111, C05011, doi:10.1029 2005JC003076.

Redfield, A., B. Ketchum, and F. Richards (1963), The influence of organisms on the composition of the sea water, in The Sea, edited by M. Hill, pp. 26-77, Wiley-Interscience, Hoboken, N. J.

Reynolds, R. W., and T. M. Smith (1994), Improved global sea surface temperature analyses using optimal interpolation, J. Clim., 7, 929-948. Rintoul, S. R., C. W. Hughes, and D. Olbers (2001), The Antarctic Circumpolar Current System, in Ocean Circulation and Climate, edited by G. Seidler, J. Church, and J. Gould, pp. 271-302, Academic, Barcelona Rogers, J. C., and H. van Loon (1982), Spatial variability of sea level pressure and $500 \mathrm{mb}$ height anomalies over the Southern Hemisphere, Mon. Weather Rev., 110, 1375-1392.

Roy, T., P. J. Rayner, R. J. Matear, and R. Francey (2003), Southern Hemisphere ocean $\mathrm{CO}_{2}$ uptake: Reconciling atmospheric and oceanic estimates, Tellus, Ser. B, 55, 701-710.

Russell, J. L., and J. M. Wallace (2004), Annual carbon dioxide drawdown and the northern annular mode, Global Biogeochem. Cycles, 18, GB1012, doi:10.1029/2003GB002044.

Sabine, C. L., and R. M. Key (1998), Controls on $\mathrm{f}\left(\mathrm{CO}_{2}\right)$ in the South Pacific, Mar. Chem., 60, 95-110.

Sabine, C. L., et al. (2004), The oceanic sink for anthropogenic $\mathrm{CO}_{2}$, Science, 305, 367-371.

Sabine, C. L., R. M. Key, A. Kozyr, R. A. Feely, R. Wanninkhof, F. J. Millero, T.-S. Peng, J. L. Bullister, and K. Lee (2005), Global Ocean data Analysis Project (GLODAP): Results and data, NDP-083, 110 pp., Carbon Dioxide Inf. Anal. Cent., Oak Ridge Natl. Lab., Oak Ridge, Tenn.

Sarmiento, J. L., N. Gruber, M. A. Brzezinski, and J. P. Dunne (2004a) High-latitude controls of thermocline nutrients and low latitude biological productivity, Nature, 427, 56-60.

Sarmiento, J. L., et al. (2004b), Response of ocean ecosystems to climate warming, Global Biogeochem. Cycles, 18, GB3003, doi:10.1029/ 2003GB002134

Schlitzer, R. (2002), Carbon export fluxes in the Southern Ocean: Results from inverse modeling and comparison with satellite-based estimates, Deep Sea Res., Part II, 49, 1623-1644.

Speer, K. G., S. R. Rintoul, and B. M. Sloyan (2000), The diabatic deacon cell, J. Phys. Oceanogr., 30, 3212-3222

Suess, E. (1980), Particulate organic carbon flux in the ocean-surface, productivity and oxygen utilization, Nature, 260-263.

Talley, L. D. (2003), Shallow, intermediate and deep overturning components of the global heat budget, J. Phys. Oceanogr., 33, 3213-3226.

Thompson, D. W. J., and S. Solomon (2002), Interpretation of recent Southern Hemisphere climate change, Science, 296, 895-899.

Trull, T. W., S. G. Bray, S. J. Manganini, S. Honjo, and R. Francois (2001a), Moored sediment trap measurements of carbon export in the Subantarctic and Polar Frontal Zones of the Southern Ocean, south of Australia, J. Geophys. Res., 106, 31,489-31,509.

Trull, T. W., S. R. Rintoul, M. Hadfield, and E. R. Abraham (2001b), Circulation and seasonal evolution of polar waters south of Australia: Implications for iron fertilizations for the Southern Ocean, Deep Sea Res., Part II, 48, 2439-2466.

Visbeck, M., and A. Hall (2004), Comments on "Synchronous variability in the Southern Hemisphere atmosphere, sea ice and ocean resulting from the annular mode"-Reply, J. Clim., 17, 2255-2258.

Walsh, J. (1978), A data set on Northern Hemisphere sea ice extent, $1953-$ 1976, Glaciological Data, Rep. GD-2, World Data Cent. for Glaciol., Boulder, Colo.

Wanninkhof, R. (1992), Relationship between wind speed and gas exchange over the ocean, J. Geophys. Res., 97, 7373-7382.

Yamanaka, Y., and E. Tajika (1996), The role of vertical fluxes of particulate organic material and calcite in the oceanic carbon cycle: Studies using a ocean biogeochemical general circulation model, Global Biogeochem. Cycles, 10, 361-382.

Zwally, H. J., J. Comiso, C. Parkinson, W. Campbell, F. Carsey, and P. Gloerson (1983), Antarctic Sea Ice, 1973-1976: Satellite Passive Microwave Observations, 206 pp., NASA Goddard Space Flight Cent. Greenbelt, Md.

A. Lenton, Laboratoire d'Océanographie et du Climat: Expérimentations et Approches Numériques (LOCEAN/IPSL), Université Pierre et Marie Curie, 4 place Jussieu, F-75005 Paris, France. (andrew.lenton@locean-ipsl. upmc.fr)

R. J. Matear, CSIRO Marine and Atmospheric Research (CMAR), Hobart, Tasmania, Australia. (richard.matear@csiro.au) 